MARIA NOGUEIRA DE MENEZES

\title{
PAPEL DO RECEPTOR P2X7 NOS FAGÓCITOS EM RESPOSTA À INFECÇÃO PELO Plasmodium chabaudi
}

Dissertação apresentada ao Programa de Pós-Graduação em Imunologia do Instituto de Ciências Biomédicas da Universidade de São Paulo para obtenção do Título de Mestre em Ciências 
MARIA NOGUEIRA DE MENEZES

\section{PAPEL DO RECEPTOR P2X7 NOS FAGÓCITOS EM RESPOSTA À INFECÇÃO PELO Plasmodium chabaudi}

Dissertação apresentada ao Programa de PósGraduação em Imunologia do Instituto de Ciências Biomédicas da Universidade de São Paulo, para obtenção do Título de Mestre em Ciências.

Área de concentração: Imunologia

Orientadora: Profa. Dra. Maria Regina D’Império Lima

Versão original 
DADOS DE CATALOGAÇÃO NA PUBLICAÇÃO (CIP)

Serviço de Biblioteca e Informação Biomédica do

Instituto de Ciências Biomédicas da Universidade de São Paulo

(c) reprodução total

Menezes, Maria Nogueira de.

Papel do receptor P2X7 nos fagócitos em resposta à infecção pelo Plasmodium chabaudi / Maria Nogueira de Menezes. -- São Paulo, 2013.

Orientador: Profa. Dra. Maria Regina D'Império Lima.

Dissertação (Mestrado) - Universidade de São Paulo. Instituto de Ciências Biomédicas. Departamento de Imunologia. Área de concentração: Imunologia. Linha de pesquisa: Imunologia das doenças infecciosas (Malária).

Versão do título para o inglês: Role of $\mathrm{P} 2 \mathrm{X} 7$ receptor in the response of phagocytes to Plasmodium chabaudi infection.

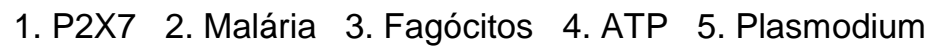
6. Imunidade inata I. Lima, Maria Regina D'Império II. Universidade de São Paulo. Instituto de Ciências Biomédicas. Programa de PósGraduação em Imunologia III. Título. 
Candidato(a):

Título da Dissertação:

Orientador(a):
Maria Nogueira de Menezes.

Papel do receptor P2X7 nos fagócitos em resposta à infecção pelo Plasmodium chabaudi.

Profa. Dra. Maria Regina D'Império Lima.

A Comissão Julgadora dos trabalhos de Defesa da Dissertação de Mestrado, em sessão pública realizada a considerou

\section{( ) Aprovado(a)}

( ) Reprovado(a)

Examinador(a): Assinatura:

Nome:

Instituição:

Examinador(a): Assinatura:

Nome:

Instituição:

Presidente: Assinatura:

Nome:

Instituição: 


\section{Certificado}

Certificamos que o protocolo registrado sob $\mathrm{n}^{\circ} \mathbf{1 7 5}$ nas fls. $\mathbf{1 1 4}$ do livro 02 para uso de animais em experimentação, sob a responsabilidade do Prof(a) $\operatorname{Dr}(a)$ ) Maria Regina D`Império Lima, Coordenador (a) da Linha de pesquisa "Avaliação da resposta imune na malária murina causada pelo Plasmodium Chobaudi" do qual participam o(s) aluno(s) Érika Machado de Salles, Maria Nogueira de Menezes e a pesquisadora Sheyla Inés Castillo Méndez, está de acordo com os Princípios Éticos de Experimentação Animal adotado pela Sociedade Brasileira de Ciência de Animais de Laboratório (SBCAL) e foi aprovado pela COMISSÃO DE ÉTICA NO USO DE ANIMAIS (CEUA) em 14.12.2011, com validade de 4 anos.

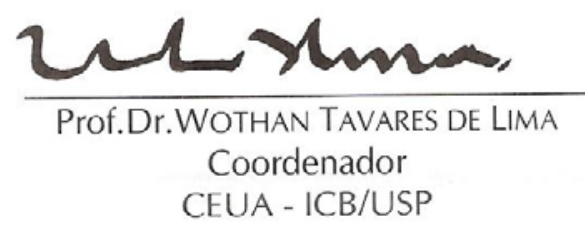

São Paulo, 15 de dezembro de 2011.

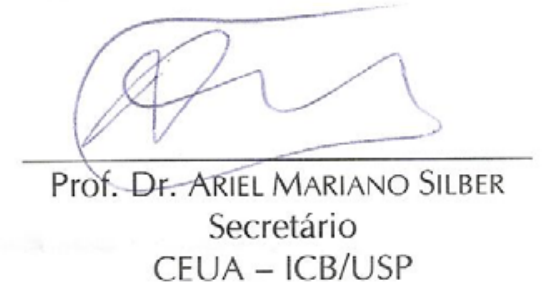




\section{AGRADECIMENTOS}

A Dra. Maria Regina D'Império Lima, pela oportunidade a mim dada para iniciar o mestrado em seu laboratório e pela excelente orientação concedida durante todo o desenvolvimento do trabalho.

A minha família, por todo o apoio dado, mesmo à distância, estando sempre presente nos momentos mais importantes. Principalmente a meu pai, o qual sempre incentivou e deu todo o apoio necessário para que eu sempre tivesse a melhor educação.

Aos colegas do Laboratório de Imunologia das Doenças Infecciosas, que fizeram do trabalho um ambiente agradável, sempre me ajudando quando foi preciso e oferecendo todo tipo de apoio.

Em especial, a Erika Salles, a qual me ensinou e ajudou muito durante todo o desenvolvimento do projeto, tendo sido elemento essencial para que hoje eu tenha esta dissertação.

Aos amigos de Salvador e de São Paulo, que sempre me deram alegrias para superar a distância da cidade natal, colaborando no incentivo ao prosseguimento do meu mestrado aqui em São Paulo.

A FAPESP e CNPq, pelo apoio financeiro, oferecendo a oportunidade para a realização deste mestrado na USP. 
Este trabalho foi realizado no Laboratório de Imunologia das Doenças Infecciosas (Malária e Tuberculose) do Departamento de Imunologia, do Instituto de Ciências Biomédicas da Universidade de São Paulo, com o auxílio financeiro da FAPESP (Fundação de Amparo à Pesquisa do Estado de São Paulo), projeto número 2011/14836-8. 


\section{RESUMO}

Menezes MN. Papel do receptor P2X7 nos fagócitos em resposta à infecção pelo Plasmodium chabaudi. [dissertação (Mestrado em Imunologia)]. São Paulo: Instituto de Ciências Biomédicas, Universidade de São Paulo; 2013.

O rompimento eritrocítico característico do ciclo de vida do Plasmodium resulta na liberação de diversas moléculas no meio extracelular, dentre estas o ATP. O P2X7 é um receptor purinérgico que reconhece o ATP extracelular, levando a diferentes efeitos nos tipos celulares. O estudo da malária experimental causada pelo $P$. chabaudi em camundongos $\mathrm{P} 2 \times 7^{-/-}$mostraram que estes animais são mais suscetíveis à infecção, apresentando uma letalidade de até $80 \%$. Diante da importância dos fagócitos no controle da doença na fase aguda da infecção, estes foram avaliados quanto à sensibilidade ao ATP através de ensaios de permeabilização. Tanto in vitro, como ex vivo, as populações celulares fagocíticas mostraram-se sensíveis ao ATP extracelular, de uma forma P2X7 dependente, e a infecção pelo $P$. chabaudi mostrou ser um fator que aumenta esta sensibilidade. Estudos fenotípicos do baço e do fígado dos animais $\mathrm{P} 2 \mathrm{X} 7^{-/-}$indicaram que, com exceção da população $\mathrm{CD} 11 \mathrm{~b}^{+} \mathrm{Ly}_{6 \mathrm{G}}{ }^{+}$, estes animais apresentam número inferior de células fagocíticas quando comparados aos animais C57BL/6. Além disso, foi observada uma leve deficiência na ativação dos fagócitos, na produção de IFN-ץ e no número de células produtoras de citocinas importantes, como IFN- $\gamma$, TNF- $\alpha$ e IL10 nos animais $\mathrm{P} 2 \times 7^{-1-}$ em relação aos C57BL/6. A maior suscetibilidade dos camundongos $\mathrm{P} 2 X 7^{-1-}$ à infecção pelo $P$. chabaudi deve-se, portanto, a uma resposta imunológica deficiente nestes animais, representada por um menor número de células do sistema imune no baço e fígado destes animais e consequentemente, menor produção de fatores importantes para o controle da infecção.

Palavras-chave: P2X7. Malária. Fagócitos. ATP. Plasmodium. Imunidade inata. 


\begin{abstract}
Menezes MN. Role of P2X7 receptor in the response of phagocytes to Plasmodium chabaudi infection. [Masters thesis (Immunology)]. São Paulo: Instituto de Ciências Biomédicas, Universidade de São Paulo; 2013.

The erythrocyte rupture is a step of the life cycle of Plasmodium in which several molecules, including ATP, are released in the extracellular milieu. The P2X7 receptor is a purinergic receptor that recognizes extracellular ATP triggering many responses depending on the cell type involved. The study of experimental malaria caused by $P$. chabaudi in $\mathrm{P} 2 \times 7^{-/-}$mice showed that these mice are more susceptible to the infection, with a lethality of $80 \%$. Since phagocytes are very important to control parasitemia at acute phase of the disease, we decided to evaluate the sensitivity of these cells to ATP through permeabilization assays. Either in vitro or ex vivo, the phagocyte cell populations were sensible to extracellular ATP in a P2X7-dependent way and the $P$. chabaudi infection acted as a component that increases this sensitivity. Phenotypic analysis of the spleen and liver from $\mathrm{P} 2 X 7^{-/-}$mice showed that, excepted for the $\mathrm{CD} 11 \mathrm{~b}^{+} \mathrm{Ly}_{6 \mathrm{G}}{ }^{+}$population, these mice have a lower number of phagocyte cells when compared to C57BL/6 mice. Furthermore, there was a slight deficiency in phagocyte activation, IFN-y production and number of cells that produce important cytokines as IFN- $\gamma, \mathrm{IL}-10$ and TNF- $\alpha$ in $\mathrm{P} 2 \times 7^{-/-}$mice in comparison with $\mathrm{C} 57 \mathrm{BL} / 6$ mice. The increased susceptibility of $\mathrm{P} 2 \times 7^{-/-}$mice to the $P$. chabaudi infection is due to a deficient immune response, with a lower number of cells from immune system in the spleen and liver of these animals and, thus, lower production of important factors that help to control the infection.
\end{abstract}

Keywords: P2X7. Malaria. Phagocytes. ATP. Plasmodium. Innate Immunity. 


\section{LISTA DE ABREVIATURAS E SIGLAS}

ATP - Adenosine Triphosphate (Trifosfato de adenosina)

DAMP - Damage-Associated Molecular Patterns (Padrões moleculares associados ao dano)

DC - Dendritic cell (Célula dendrítica)

EN - Eritrócito não-parasitado

EP - Eritrócito parasitado

GPI - Glicofosfatidilinositol

IFN - Interferon

IL- Interleucina

LPS - Lipopolissacarídeo

mAb - Monoclonal Antibody (Anticorpo monoclonal)

M-CSF - Macrophage Colony-Stimulating Factor (Fator estimulante de colônia de macrófagos)

MHC - Major Histocompatibility Complex (Complexo principal de

histocompatibilidade)

NO - Nitric Oxide (Óxido nítrico)

PAMP - Pathogen-Associated Molecular Patterns (Padrões moleculares associados a patógenos)

PfEMP1 - Plasmodium falciparum erythrocyte membrane protein 1 (Proteína 1 de membrana de eritrócito de Plasmodium falciparum)

PRR - Pattern Recognition Receptor (Receptor de reconhecimento de padrão)

SFB - Soro fetal bovino

TGF - Transforming Growth Factor (Fator de transformação do crescimento)

TLR - Toll-like Receptor (Receptor do tipo Toll)

TNF - Tumor necrosis factor (Fator de necrose tumoral) 
1 INTRODUÇÃO

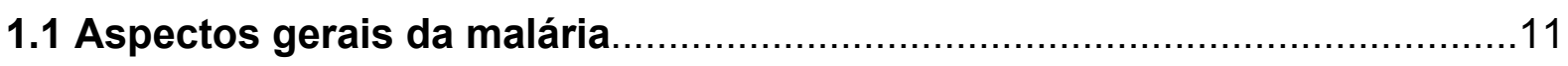

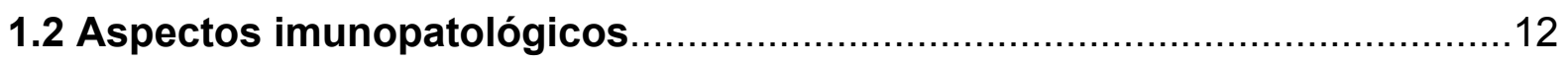

1.30 modelo murino de malária causada pelo Plasmodium chabaudi.............15

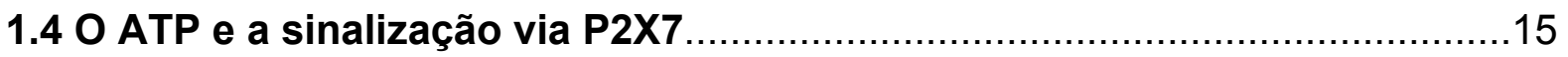

2 OBJETIVOS

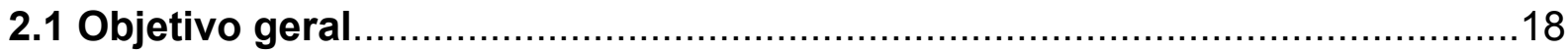

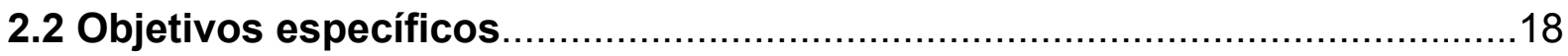

3 MATERIAL E MÉTODOS

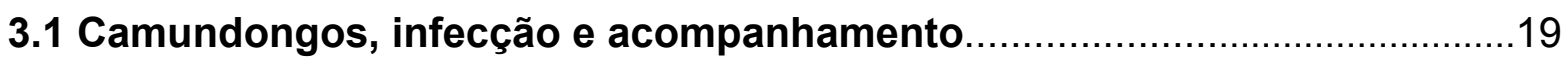

3.2 Obtenção dos macrófagos derivados da medula óssea..............................19

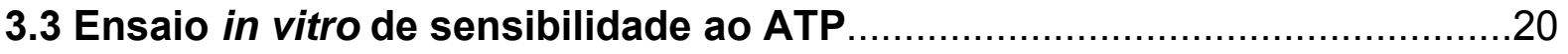

3.4 Preparação de células do baço e análise por citometria .............................20

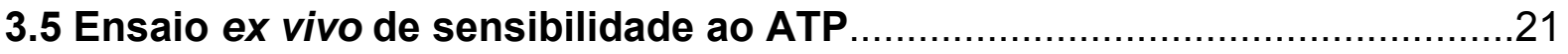

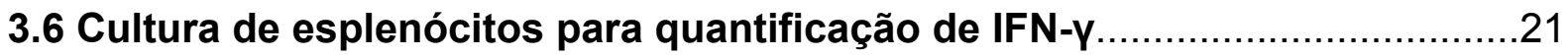

3.7 Preparação das células do fígado e análise por citometria.........................22

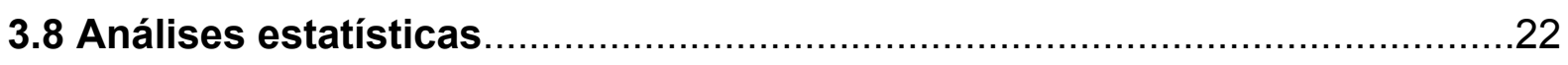

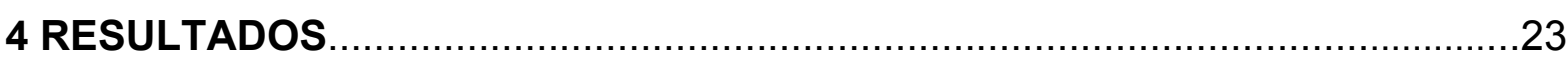

4.1 Comparação da parasitemia e manifestações clínicas em camundongos

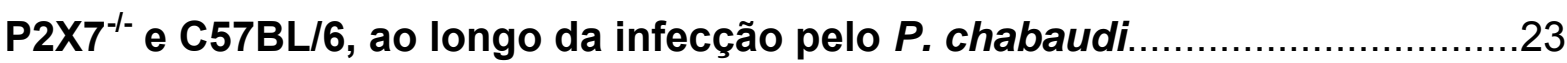

4.2 Sensibilidade ao ATP de populações celulares fagocíticas in vitro e ex vivo.

4.3 Análise fenotípica das populações de fagócitos do baço de camundongos C57BL/6 e P2X7-1-

4.4 Produção de citocinas no baço dos camundongos $\mathrm{P} 2 \mathrm{X} 7^{-1-} \mathrm{em}$ comparação aos animais C57BL/6.

4.5 Análise fenotípica das populações de células que infiltram o fígado dos camundongos $\mathrm{C} 57 \mathrm{BL} / 6$ e $\mathrm{P} 2 \mathrm{X}^{-/-} \mathrm{em}$ resposta à infecção pelo $P$.

chabaudi...

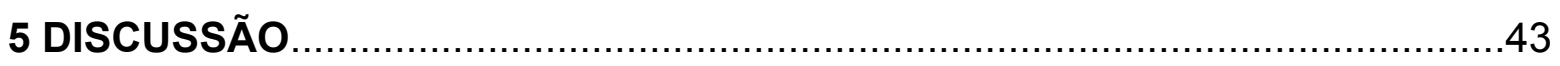

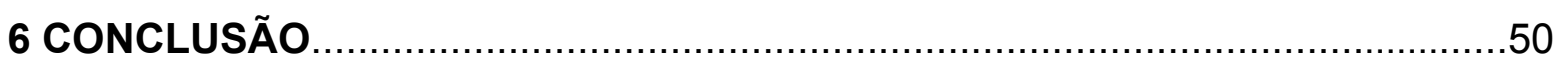

REFERÊNCIAS 


\section{INTRODUÇÃO}

\subsection{Aspectos gerais da malária}

O termo malária é derivado do italiano "mal'aria", que significa "mal ar", devido à associação de febres intermitentes com a exposição ao ar de áreas pantanosas. Próximo ao fim do século XIX, Charles Louis Alphonse Laveran, cirurgião do exército francês, observou parasitas no sangue de um paciente sofrendo de malária, e o Dr. Ronald Ross, médico oficial britânico em Hyderabad, Índia, descobriu que mosquitos transmitiam a malária [1]

A distribuição dos casos de malária abrange países tropicais e subtropicais, com muitas áreas tropicais sendo consideradas endêmicas para a doença. Segundo levantamento da Organização Mundial da Saúde, a situação da doença no ano de 2010 consiste em uma estimativa de 216 milhões de casos em todo o mundo, com 655 mil mortes, sendo que $86 \%$ destas acometem crianças abaixo dos cinco anos de idade [2]. Na região das Américas, a transmissão da malária ocorre em 21 países e cerca de $20 \%$ da população corre risco de contrair a doença. Além disso, somente o Brasil é responsável por mais de $50 \%$ dos casos desta região.

A malária é uma doença parasitária causada por protozoários pertencentes ao filo Apicomplexa e ao gênero Plasmodium. Para seres humanos, quatro espécies são bem estabelecidas como agentes etiológicos da malária: Plasmodium falciparum, Plasmodium malariae, Plasmodium vivax e Plasmodium ovale. Cinco espécies de Plasmodium que infectam macacos foram relatadas como potenciais agentes infecciosos para humanos [3]. Dentre estas espécies, Plasmodium knowlesi foi proposto como o quinto patógeno responsável pela malária humana, por ser capaz de infectar humanos com um impacto epidemiológico significante principalmente no sudeste asiático [4]. A transmissão da doença ocorre por meio de mosquitos do gênero Anopheles infectados com o parasito. De aproximadamente 400 espécies conhecidas de Anopheles, cerca de 60 são vetores da malária em condições naturais [1].

O combate à malária pode se dar por mecanismos de controle do vetor e através do tratamento dos pacientes, prevenindo a transmissão da doença e a mortalidade causada por ela, uma vez que ainda não há uma vacina para esta doença. Uma vacina eficiente contra a malária deve conceber uma imunidade 
protetora que seja maior do que aquela adquirida pela exposição natural à doença [5]. As principais dificuldades encontradas para o desenvolvimento de uma vacina eficaz são o tamanho e plasticidade do genoma do Plasmodium, além das diferenças encontradas em cada uma das fases do parasito ao longo do seu ciclo de vida e da diversidade genética conferida pela fase sexual de sua reprodução [6]. Outro problema crescente do combate à malária é a resistência às drogas antimaláricas usadas no tratamento de pacientes. Diante desta situação, o estudo da relação parasito-hospedeiro na malária é de grande importância para o estabelecimento de novos alvos terapêuticos ou de estratégias de vacinas para combater a malária.

\subsection{Aspectos imunopatológicos}

A infecção inicia-se no momento em que a fêmea do Anopheles, que possui hábito hematófago, realiza o repasto sanguíneo e inocula, juntamente com sua saliva, de 15 a 200 esporozoítos, formas infectantes do parasito, que alcançam a corrente sanguínea do hospedeiro. Alguns minutos depois, os esporozoítos alcançam os hepatócitos, invadindo-os e iniciando a fase pré-eritrocítica do seu ciclo biológico. Há uma forma latente do parasito, chamada de hipnozoíto, presente apenas em $P$. ovale e $P$. vivax, que se mantém no fígado sem iniciar o processo de esquizogonia, e que é provavelmente a responsável por recaídas anos após a infecção. Uma vez dentro do hepatócito, o esporozoíto se diferencia em trofozoíto pré-eritrocítico que irá iniciar a reprodução assexuada por esquizogonia. Os hepatócitos parasitados se rompem e liberam os merossomos na corrente sanguínea [7], os quais, após romperem-se, liberam milhares de merozoítos. A invasão dos eritrócitos pelos merozoítos caracteriza o início da fase eritrocítica do ciclo de vida do Plasmodium. No interior do eritrócito, o parasito passa pelas fases de trofozoíto jovem, trofozoíto maduro e volta a realizar sucessivas divisões dando origem ao esquizonte, que ao romper-se, volta a liberar novos merozoítos que irão infectar novos eritrócitos. Alguns dias após as primeiras manifestações clínicas da doença, uma pequena porção dos merozoítos liberados na corrente sanguínea diferenciam-se em gametócitos masculinos e femininos, que serão ingeridos pelo mosquito em um novo repasto sanguíneo, dando início à fase sexual do ciclo de vida do parasito no interior do mosquito. 
Diversos componentes do parasito podem funcionar como padrões moleculares associados a patógenos (Pathogen-Associated Molecular Patterns PAMPs) que são reconhecidos pelos receptores de reconhecimento de padrão (Pattern recognition receptors - PRR) e dentre estes, os receptores do tipo Toll (Tolllike receptors - TLRs) de células da imunidade inata do hospedeiro. Âncoras de glicosilfosfatidilinositol (GPI) presentes em moléculas da superfície do Plasmodium ativam células dendríticas (Dendritic cells - DCs), macrófagos e células B através do TLR2 ou TLR4 [8, 9]. Cristais de hemozoína, ou possivelmente o DNA do parasito que possa estar associado a esses cristais resultantes da digestão da hemoglobina, são reconhecidos por TLR9 e também leva à ativação das células do sistema imune [10]. Além disso, o Plasmodium é capaz de expressar moléculas próprias na superfície do eritrócito parasitado, como é o caso da PfEMP1 (Plasmodium falciparum erythrocyte membrane protein 1 ), molécula do $P$. falciparum, que pode se ligar, dentre outras moléculas, ao receptor CD36, levando à fagocitose destes eritrócitos, além de cooperar com a sinalização via TLRs para produção de citocinas pró-inflamatórias [11]. Além do papel na produção das citocinas, os fagócitos mononucleares do sistema inato do hospedeiro também possuem outras funções fundamentais no controle da doença, como, por exemplo, a fagocitose dos eritrócitos infectados na ausência de anticorpos opsonizantes específicos [12], ajudando na redução da parasitemia na fase aguda da infecção. Em macrófagos e monócitos, a fagocitose dos eritrócitos parasitados mediada pelo CD36 é bem estabelecida, cooperando no controle da replicação dos estágios sanguíneos do parasito, e sendo, portanto, um componente essencial dos mecanismos de defesa do hospedeiro nesta fase do ciclo [13].

Após o controle da infecção aguda, uma fase crônica é estabelecida com menores densidades parasitárias e com acessos febris coincidindo com os picos desta parasitemia remanescente [14]. A imunidade adquirida à malária forma-se lentamente, provavelmente por causa da ativação policlonal dos linfócitos B, levando à produção de muitos anticorpos inespecíficos [15], e é incompleta, uma vez que uma imunidade estéril não é adquirida na maior parte das vezes. Entretanto, a imunidade à morte decorrente da doença é adquirida rapidamente, podendo ocorrer até mesmo após um único episódio infeccioso [16, 17].

A ruptura dos eritrócitos que contêm os esquizontes é tipicamente acompanhada por febre, náuseas, dores de cabeça e outros sintomas de uma 
resposta sistêmica de citocinas pró-inflamatórias oriundas, principalmente, das células do sistema imune inato [18]. Isto se deve ao fato de que a ruptura destes eritrócitos libera na corrente sanguínea os componentes bioativos do parasito, além de moléculas próprias do hospedeiro contidas nos eritrócitos, que entram em contato com as células do sistema imune desencadeando respostas imunológicas exacerbadas. Muitos estudos têm demonstrado associações entre a forma severa da malária e altos níveis de citocinas pró-inflamatórias, como TNF, interleucina $1 \beta$ (IL-

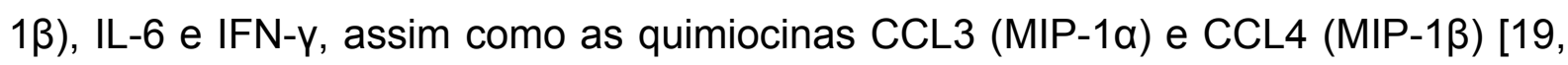
20]. Entretanto, esta resposta inflamatória também é importante para a proteção contra a doença, como, por exemplo, no caso do TNF atuando em sinergia com o IFN-y num papel antiparasitário ao induzir a produção de óxido nítrico (NO) e outros radicais tóxicos [21]. A resposta de citocinas como TGF- $\beta$ e IL-10 é essencial para regular essa resposta pró-inflamatória em diferentes momentos, já que altos níveis destas citocinas no início da infecção podem comprometer os mecanismos efetores e baixos níveis tardiamente podem não controlar a cascata inflamatória de citocinas e resultar na doença severa [22].

Além dos PAMPs liberados após a ruptura do eritrócito, moléculas do próprio hospedeiro que indicam a injúria celular também alcançam a corrente sanguínea em decorrência do rompimento eritrocítico. Estas moléculas são chamadas de DAMPs (Damage-Associated Molecular Pattern molecules) e consistem em sinais endógenos de perigo que alertam o sistema imune inato para uma morte celular não programada, invasão microbiana e em resposta ao stress [23]. O trifosfato de adenosina (Adenosine triphosphate - ATP) é um nucleotídeo que está presente em todas as células vivas do organismo e que, uma vez no espaço extracelular, pode atuar como um DAMP, além de contribuir para a regulação de diversos processos biológicos, incluindo inflamação, função cardíaca, neurotransmissão, contração muscular e vasodilatação [24]. O eritrócito parasitado apresenta altas quantidades de ATP em seu interior, o qual é também utilizado pelo próprio Plasmodium para a sua maturação, e defeitos na produção deste ATP do eritrócito podem influenciar de diversos modos a patofisiologia da malária [25]. No momento do rompimento do eritrócito parasitado, portanto, o ATP intracelular é liberado no meio extracelular de modo a entrar em contato com as células do sistema imunológico do hospedeiro, podendo desencadear diversas respostas. 


\subsection{0 modelo murino de malária causada pelo Plasmodium chabaudi}

O estudo de mecanismos imunológicos em pacientes humanos é de difícil acesso aos pesquisadores, uma vez que envolve questões éticas e de impossibilidades de procedimentos. Desta forma, o uso de roedores para estudar a imunopatologia da malária vem sendo largamente aplicado. A infecção pelo $P$. chabaudi é considerado o principal modelo para compreensão da resposta imune em infecções pelo Plasmodium [26]. A infecção de camundongos C57BL/6 com o $P$. chabaudi AS causa uma malária não letal e caracterizada por uma esplenomegalia associada a uma ativação policlonal de linfócitos T e B do baço [27-29]. As citocinas IL-12, TNF- $\alpha$ e IFN-y são produzidas em grande quantidade no baço, e estão presentes de forma transiente no plasma, tendo sido demonstrado que na ausência de IFN- $y$, os camundongos apresentam maior dificuldade para controlar e eliminar a infecção primária [30]. Além disso, camundongos deficientes na produção de IL-12 apresentam fagócitos com falha na fagocitose de eritrócitos opsonizados, além de produzirem menos IFN-y e NO, o que leva a uma dificuldade do controle parasitário na fase aguda da infecção [31]. Estudos comparativos entre animais suscetíveis e resistentes à infecção com $P$. chabaudi sugerem que as respostas pró-inflamatórias são necessárias para o subsequente desenvolvimento da imunidade protetora [32].

Com a progressão da doença, grande parte dos linfócitos $T$ e $B$ que foram ativados policlonalmente na fase aguda são eliminados por apoptose [33] e o subsequente desenvolvimento de uma resposta específica de linfócitos $T$ e $B$ resulta na eliminação do parasita e a proteção à doença. Assim como na malária humana, a imunidade que promove proteção à reinfecção parece não ser duradoura no modelo do $P$. chabaudi, o que parece ocorrer de forma independente dos anticorpos circulantes, mas sim devido a um declínio da resposta de memória de células $T$ $\mathrm{CD}^{+}[34]$.

\subsection{O ATP e a sinalização via receptor P2X7}

O ATP liberado na ruptura eritrocítica pode ser reconhecido pelos chamados receptores purinérgicos. Estes receptores são divididos em receptores do tipo P1 e do tipo P2. Enquanto os receptores do tipo P1 reconhecem a adenosina, os P2 podem ser subdivididos em $\mathrm{P} 2 \mathrm{X}$, com sete componentes, e $\mathrm{P} 2 \mathrm{Y}$, composto por oito 
subtipos de receptores, e ambos são capazes de se ligar ao ATP extracelular [35]. Os receptores da classe P2X são canais de íons que uma vez ativados pela ligação ao ATP extracelular, facilitam a entrada e saída de íons mono e divalentes, como por exemplo, o $\mathrm{Ca}^{2+}$. Enquanto que os demais receptores $\mathrm{P} 2 \mathrm{X}$ se ativam na presença de concentrações nanomolares de ATP, o receptor P2X7 ativa sua função de canal de íon na presença de concentrações micromolares do ATP extracelular, e concentrações maiores ainda são capazes de induzir a formação de um poro largo não seletivo que estaria envolvido com a morte celular mediada pelo receptor P2X7 [36]. A expressão do receptor P2X7 ocorre em praticamente todas as células do sistema imunológico dos mamíferos, incluindo os neutrófilos, macrófagos, monócitos, células dendríticas e linfócitos [24].

A sinalização via receptor $\mathrm{P} 2 \mathrm{X} 7$ pode gerar diversas consequências para as células que entram em contato com o ATP extracelular. Sabe-se que o fator de transcrição NF-kB pode ser ativado mediante estimulação do receptor $P 2 X 7$, levando à produção de citocinas e quimiocinas que têm sua expressão sob controle deste fator de transcrição em macrófagos murinos, além de regular também a produção de NO [37]. A produção de citocinas pró-inflamatórias como IL-1ß e IL-18 pode ainda ser mediada pelo receptor P2X7 a partir da ativação do inflamassoma NLRP3. O efluxo de potássio $\left(\mathrm{K}^{+}\right)$, resultante da abertura do canal do receptor P2X7 após ligação ao ATP extracelular, leva, por um mecanismo ainda desconhecido, à ativação do inflamassoma NLRP3, culminando na ativação da caspase-1 e subsequente clivagem das formas imaturas pro-IL-1 $\beta$ e pro-IL-18 nas citocinas IL-1 $\beta$ e IL-18 ativadas que serão secretadas pelas células [38]. A estimulação da NADPH e geração de ânions superóxido em células primadas com LPS relaciona a ativação do receptor $\mathrm{P} 2 \mathrm{X} 7$ à produção de espécies reativas de oxigênio [39]. Também é descrita a participação do receptor P2X7 na proliferação celular, como, por exemplo, para microglias, que em resposta ao ATP extracelular ativam-se, produzindo citocinas e proliferando [40]. Para linfócitos $T$, sabe-se que a liberação autócrina de ATP e estimulação do receptor P2X7 contribue para a ativação do linfócito e consequente síntese de IL-2 [41]. A redução na expressão de algumas moléculas de superfície também é bem descrita como efeito da sinalização via receptor P2X7, como, por exemplo, a molécula CD27, proteína transmembrana do tipo I da família do receptor de TNF, a qual tem sua expressão perdida pelos linfócitos do baço de camundongos após estimulação do receptor P2X7 pelo ATP [42]. Em monócitos, a 
estimulação do receptor $\mathrm{P} 2 \mathrm{X} 7$ resulta na perda da L-selectina expressa na superfície destas células, indicando que altas concentrações de ATP extracelular contribuam para a ativação e transmigração de monócitos aos sítios inflamatórios [43].

Além do papel na ativação das células e consequente secreção de citocinas, o reconhecimento do ATP extracelular pelo receptor P2X7 também possui ação na indução de morte celular. Tal morte celular dependente do receptor $\mathrm{P} 2 \mathrm{X} 7$ pode acontecer por mecanismos de apoptose ou necrose, dependendo do tipo celular, tempo de exposição e concentração do ATP [44]. Em linfócitos de galinha transfectados com o receptor $\mathrm{P} 2 \mathrm{X} 7$, o tratamento com ATP levou a uma morte que estaria associada com a atividade de caspase-3 e fragmentação do DNA, indicando uma morte celular do tipo apoptótica [45]. Já em macrófagos da linhagem J774, que expressam o receptor, a morte causada pelo ATP extracelular ocorre por uma lise osmótica, com rápido inchaço das células e liberação do conteúdo citoplasmático [44]. 


\section{OBJETIVOS}

\subsection{Objetivo geral}

Avaliar o papel do receptor P2X7 na cinética e na ativação das populações de células fagocíticas durante a infecção de camundongos pelo $P$. chabaudi (cepa AS).

\subsection{Objetivos específicos}

- Determinar as curvas de parasitemia e as manifestações clínicas da malária em camundongos $\mathrm{P} 2 \times 7^{-/-}$infectados com $P$. chabaudi, em comparação com os dados da linhagem C57BL/6.

- Avaliar a sensibilidade dos fagócitos ao ATP em resposta à infecção através de metodologias in vitro e ex vivo.

- Analisar fenotipicamente as populações fagocíticas do baço de camundongos C57BL/6 e P2X7 $7^{-/-}$, durante a infecção pelo $P$. chabaudi.

- Avaliar a produção de citocinas por fagócitos esplênicos, como IFN-y, IL-10 e TNF- $\alpha$, em camundongos C57BL/6 e P2X7/-.

- Analisar fenotipicamente as populações de leucócitos presentes no fígado dos animais C57BL/6 e P2X7/-. 


\section{MATERIAL E MÉTODOS}

\subsection{Camundongos, infecção e acompanhamento:}

Camundongos C57BL/6 e P2X7 $7^{-1}$, com 6 a 8 semanas de idade, foram fornecidos pelo biotério do Departamento de Imunologia da Universidade de São Paulo e mantidos em condição "specific pathogen-free" e em ciclo de claro/escuro invertido. Os camundongos $\mathrm{P} 2 \mathrm{X}^{-/-}$originalmente obtidos da Jackson Laboratory (Sacramento, CA., E.U.A.) foram fornecidos pelo Dr. Robson Coutinho Silva (Universidade Federal do Rio de Janeiro). Para infecção, os camundongos foram inoculados pela via intraperitoneal (i.p.) com $10^{6}$ eritrócitos parasitados por $P$. chabaudi (cepa AS).

As parasitemias foram monitoradas através de esfregaços sanguíneos corados com Giemsa. Foram mensurados peso e temperatura corporal dos animais infectados. A concentração de hemoglobina no sangue foi quantificada utilizando-se o kit colorimétrico para detecção de hemoglobina no sangue total da Doles Reagentes (Goiânia, GO., Brasil).

\subsection{Obtenção dos macrófagos derivados da medula óssea:}

Células precursoras da medula óssea dos camundongos C57BL/6 e P2X7 $7^{-1-}$ foram coletadas assepticamente de ambos os fêmures com auxílio de tesoura e pinça e colocadas em meio DMEM-F12 acrescido de $10 \%$ soro fetal bovino (SFB), penicilina $(100 \mathrm{U} / \mathrm{ml})$, estreptomicina $(100 \mu \mathrm{g} / \mathrm{ml}), 2$,mercaptoetanol $(50 \mu \mathrm{M})$, Lglutamina $(2 \mathrm{mM})$, piruvato de sódio $(1 \mathrm{mM})$. Todas as soluções e suplementos foram adquiridos da Life Technologies (Carlsbad, CA., E.U.A.). A cultura foi mantida durante a noite na estufa a $37^{\circ} \mathrm{C}$, para seleção negativa das células já diferenciadas que aderem na placa. No dia seguinte foi coletado o sobrenadante, contendo os precursores mielóides da medula que foram então cultivados em meio acrescido de $20 \%$ de meio condicionado da cultura de células da linhagem de fibroblastos L929, como fonte de M-CSF (Macrophage Colony-Stimulating Factor) [46]. A cultura, contendo o meio de diferenciação celular, foi incubada na estufa a $37^{\circ} \mathrm{C}$. Após três dias de incubação foi acrescido mais meio de cultura suplementado com 
sobrenadante de células L929 e no sétimo dia de diferenciação, os macrófagos estavam prontos para uso em experimento.

\subsection{Ensaio in vitro de sensibilidade ao ATP:}

Em placas de 96 poços, foram plaqueados $5 \times 10^{4}$ macrófagos derivados da medula óssea de camundongos C57BL/6 ou P2X7-1- por poço, em um volume de $200 \mu \mathrm{l}$ de meio DMEM-F12 suplementado e deixados em repouso, a $37^{\circ} \mathrm{C}$, por 6 horas. As amostras foram incubadas, a $37^{\circ} \mathrm{C}$, com LPS (Lipopolissacarídeo) a $1 \mu \mathrm{g} / \mathrm{ml}$ (Escherichia coli 0111:B4, Sigma-Aldrich, St. Louis, MO., E.U.A.), por 3 horas, ou com eritrócitos parasitados em uma proporção de 10 eritrócitos parasitados para cada macrófago, por 12 horas. O LPS e os eritrócitos parasitados foram removidos por meio de lavagens. Posteriormente, foi acrescentado o ATP diluído em meio de cultura, em diferentes concentrações, e as células foram deixadas em estufa a $37^{\circ} \mathrm{C}$ por 24 horas. A leitura em microscópio de fluorescência foi realizada através da marcação de permeabilização da membrana com uma solução 1:1 de laranja de acridina com brometo de etídio.

\subsection{Preparação de células do baço e análise por citometria:}

O baço foi extraído dos animais no dia 7 pós-infecção e processados para obtenção das células. As células foram lavadas e mantidas em RPMI 1640 gelado e suplementado com penicilina $(100 \mathrm{U} / \mathrm{ml})$, estreptomicina $(100 \mu \mathrm{g} / \mathrm{ml})$, 2mercaptoetanol $(50 \mu \mathrm{M})$, L-glutamina $(2 \mathrm{mM})$, piruvato de sódio $(1 \mathrm{mM})$ e $3-20 \%$ de SFB inativado pelo calor. O número de células por baço foi contado utilizando a câmara de Neubauer (Sigma-Aldrich). As células esplênicas $\left(10^{6}\right)$ foram marcadas com anticorpos monoclonais (mAbs) anti-CD3, B220, CD45, DX5 (CD49b), CD11c, CD11b, F4/80 e MHCll obtidos da BD Pharmingen (Franklin Lakes, N.J., E.U.A.), conjugados à fluoresceína (FITC), ficoeritrina (PE), aloficocianina (APC), complexo proteína clorofila peridinina (PerCP), ficoeritrina-Cy7 (PE-Cy7), aloficocianina-Cy7 (APC-Cy7). Para a deteç̧ão intracelular de citocinas os esplenócitos $\left(10^{6}\right.$ células/poço) foram colocados em cultura na presença ou ausência de anticorpos anti-CD3 $(5 \mu \mathrm{g} / \mathrm{mL})$ e anti-CD28 $(5 \mu \mathrm{g} / \mathrm{mL})$ solúveis, overnight, em meio contendo Stop Golgi (BD Pharmingen) e mantidos por 12 horas à $37{ }^{\circ} \mathrm{C}$ e $5 \%$ de $\mathrm{CO}_{2}$. As 
células foram marcadas extracelularmente com os mAb anti-CD4, CD11b, CD11c e F4/80 (BD PharMingen) e em seguida, os esplenócitos foram fixados com tampão Cytofix/Cytoperm (BD PharMingen) e permeabilizados com PermWash (BD PharMingen). Os esplenócitos foram marcados internamente com os mAbs anti-IFN$\gamma$, anti-IL-10 e anti-TNF- $\alpha$ conjugados com os fluorocromos descritos acima (BD PharMingen). As amostras foram captadas em citômetro de fluxo BD FACSCanto e os dados analisados utilizando-se o programa FlowJo (Treestar Inc., Ashland, OR., E.U.A.).

\subsection{Ensaio ex vivo de sensibilidade ao ATP:}

As células extraídas do baço, processadas e marcadas conforme descrito no item anterior foram plaqueadas $\left(10^{6}\right)$ em placas de 96 poços e foi então adicionado ATP (Pharmacia LKB Biotechnology, Uppsala, Suécia) extracelular nas concentrações de 0, 25, 50,100, 300 e $500 \mu \mathrm{M}$ juntamente com brometo de etídio $(100 \mu \mathrm{M})$. As células foram deixadas em repouso por quinze minutos em estufa a 37 ${ }^{\circ} \mathrm{C}$ e a leitura da incorporação de brometo de etídio foi realizada imediatamente depois no citômetro de fluxo.

\subsection{Cultura de esplenócitos para quantificação de IFN-Y:}

O baço dos animais foi extraído e processado conforme descrito anteriormente. As células $\left(1 \times 10^{8}\right)$ foram marcadas com beads magnéticas acopladas a mAb anti-CD8 e CD19 (MACS; Miltenyi Biotec, Bergisch Gladbach, Alemanha) em PBS 0,5\% BSA 2mM EDTA (Life Technologies). Estas células foram então separadas usando colunas Ls (Midi MACS; Mlltenyi Biotec) e a fração negativa ( $C D 4^{+}$e fagócitos) foi contada e plaqueada $\left(5 \times 10^{5}\right.$ células/poço) com ou sem eritrócitos parasitados $\left(1,5 \times 10^{6} /\right.$ poço) e mantida em cultura por 72 horas em estufa a $37^{\circ} \mathrm{C}$. O sobrenadante foi coletado ao final das 72 horas e a presença de IFN-y foi quantificada utilizando-se o kit de ELISA para detecção de IFN-ץ (BD Biosciences) conforme as instruções do fornecedor. 


\subsection{Preparação das células do fígado e análise por citometria:}

O fígado dos animais foi extraído e o lobo esquerdo foi perfundido com a ajuda de seringa com solução de PBS estéril. Após a perfusão, foi inserido meio RPMI suplementado como descrito acima acrescido de $0,2 \%$ de colagenase do tipo II (Life Technologies). Em seguida, o fígado, na presença do meio com colagenase, foi processado em pequenos pedaços e deixado na estufa a $37^{\circ} \mathrm{C}$ por 30 minutos. Após este período, foi realizada a maceração do material e posterior centrifugação. Após duas lavagens, foi realizada a lise das hemácias para que restassem apenas as células a serem utilizadas no estudo. A marcação e leitura no citômetro de fluxo foi realizada da mesma forma descrita para o baço.

\subsection{Análises estatísticas:}

A análise estatística foi realizada com o teste "Two-way ANOVA", seguido por análise do Teste de Bonferroni. Todas as análises estatísticas foram realizadas no programa Prisma 4 (Graph Pad Software, La Jolla, CA., E.U.A.)) e as diferenças entre os três grupos foram consideradas significativas para valores de $p<0,05(5 \%)$. 


\section{RESULTADOS}

\subsection{Comparação da parasitemia e manifestações clínicas em camundongos $\mathrm{P} \mathrm{X7}^{-1 /}$ e C57BL/6, ao longo da infecção pelo $P$. chabaudi}

Com o intuito de identificar possíveis diferenças na malária desenvolvida pelos animais, camundongos $\mathrm{C} 57 \mathrm{BL} / 6$ e $\mathrm{P} 2 \mathrm{X} 7^{-1 /}$ machos foram infectados com $10^{6}$ eritrócitos parasitados e a partir do dia 4 pós-infecção tiveram sua parasitemia quantificada. Além disso, foram mensurados peso, temperatura e concentração de hemoglobina no sangue destes animais.

Entre os dias 9 e 17 pós-infecção, houve uma mortalidade de $80 \%$ dos camundongos $\mathrm{P} 2 \mathrm{X} 7^{-/-}$, enquanto que não houve mudança na sobrevivência dos animais C57BL/6 (Figura 1a). O pico de parasitemia dos animais knockout se deu no dia 8 pós-infecção, o que representa um atraso comparado ao pico dos animais C57BL/6 (Figura 1b), que aconteceu no dia 7 pós-infecção. Os animais da linhagem C57BL/6 apresentaram uma queda de peso, temperatura e concentração de hemoglobina a partir do dia 6 pós-infecção, e uma recuperação destes parâmetros aos níveis normais a partir do dia 9 pós-infecção. Já os animais knockout para o receptor P2X7 apresentaram o mesmo comportamento de queda nos parâmetros patológicos a partir do dia 6 pós-infecção, no entanto, não foram capazes de restaurar tais parâmetros às condições normais e culminando na mortalidade dos animais (Figura 1c-e). Tais resultados sugerem, portanto, que os camundongos $\mathrm{P} 2 \mathrm{X}^{-/-}$são mais suscetíveis à malária causada pelo $P$. chabaudi, que chegou a ser letal para $80 \%$ dos animais e, além disso, apresentaram manifestação dos sinais clínicos da doença de forma atrasada ou até mesmo incapaz de restaurar as condições fisiológicas.

\subsection{Sensibilidade ao ATP de populações celulares fagocíticas in vitro e ex vivo}

Uma vez que as populações celulares fagocíticas exercem um importante papel na resposta à malária ao fagocitar os eritrócitos infectados, entrando em contato com os antígenos do Plasmodium, e colaborando na limpeza da parasitemia 
(a) Curva de sobrevivência em camundongos C57BL/6 e P2X7-/- infectados pelo P. chabaudi ao longo da infecção. (b) Parasitemia quantificada por contagem de eritrócitos parasitados em esfregaço sanguíneo corado com Giemsa a partir do $4^{\circ}$ dia de infecção. (c) Mudança de peso, (d) temperatura e (e) concentração de hemoglobina (em $\mathrm{g} / \mathrm{dL}$ ) dos animais ao longo da infecção. Os valores fazem referência a cada um dos animais, uma vez que os animais $\mathrm{P} 2 \times 7^{-/-}$tiveram sua mortalidade iniciada a partir do dia 8 pós-infecção. Dados representativos de dois experimentos realizados separadamente $(n=5)$. 
Figura 1 - Sobrevivência e manifestações clínicas ao longo da infecção por $P$. chabaudi em camundongos C57BL/6 e P2X7 ${ }^{-/ 2}$.

a

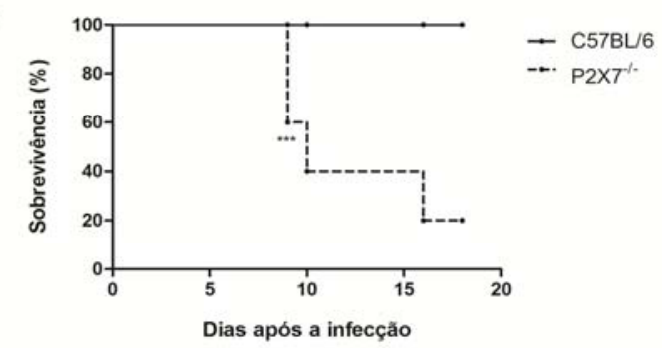

C57BL/6

b

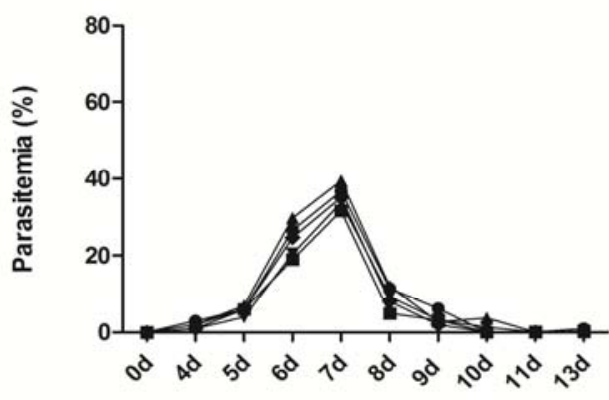

c

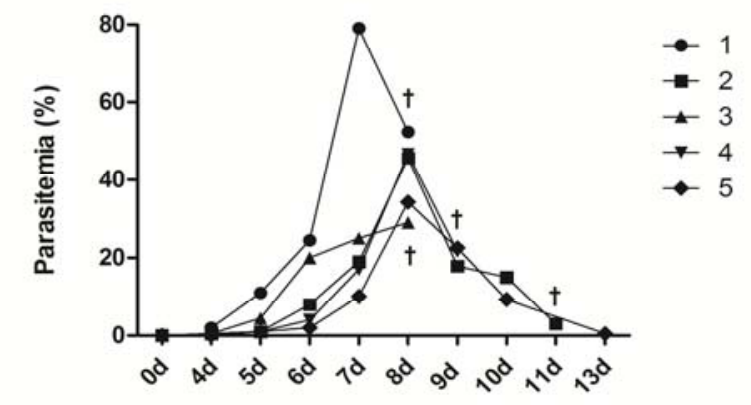

Dias após a infecção

Dias após a infecção
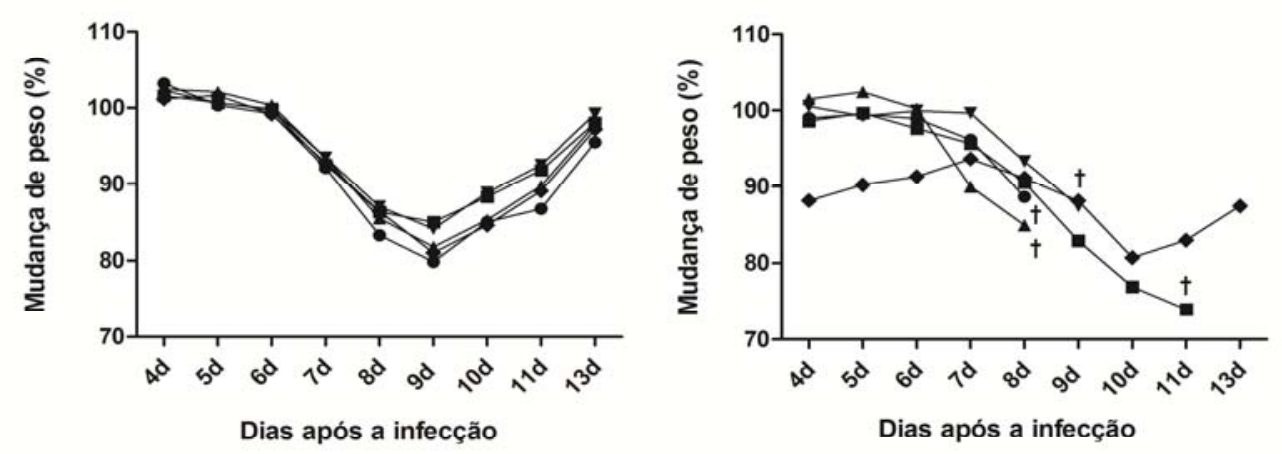

d
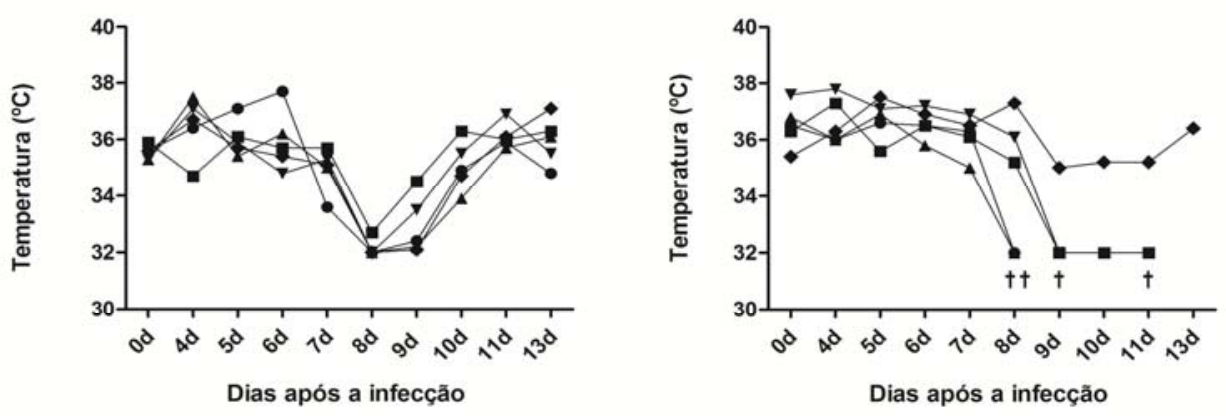

e
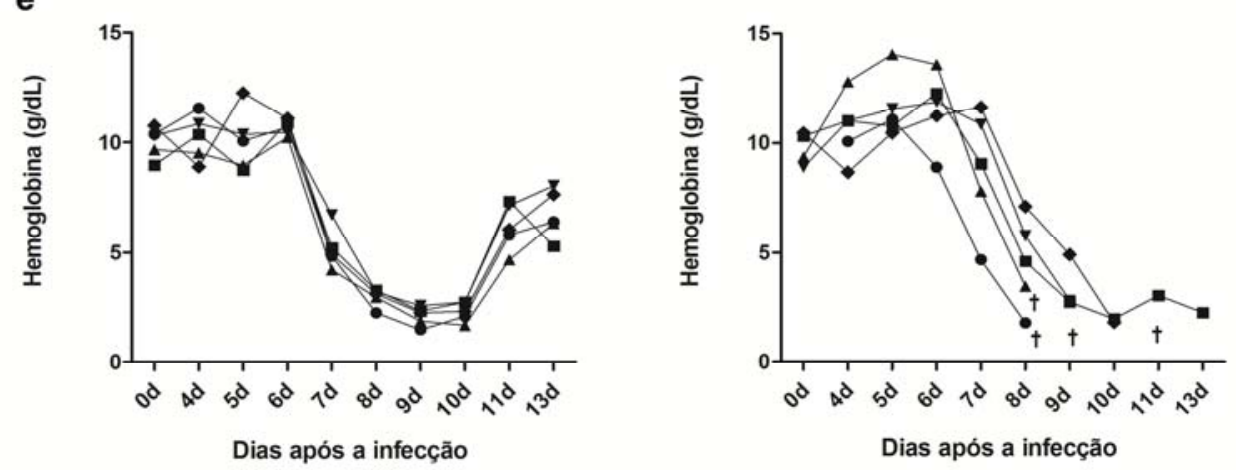
na fase aguda da infecção, buscou-se avaliar se a interação dos fagócitos com os eritrócitos parasitados no contexto da infecção exerce algum efeito na resposta destas células ao ATP.

A sensibilidade ao ATP das células fagocíticas foi avaliada através da incorporação de brometo de etídio, uma vez que a estimulação do receptor P2X7 provoca a abertura de um poro permeável à passagem do brometo. Este parâmetro de incorporação de brometo de etídio mensurando a permeabilização das células em resposta ao ATP foi utilizado no ensaio ex vivo com fagócitos extraídos do baço de camundongos no $4^{\circ}$ dia de infecção pelo $P$. chabaudi. As populações celulares positivas para os marcadores de fagócitos CD11c, CD11b e F4/80 extraídas do baço de camundongos C57BL/6 infectados mostraram-se mais sensíveis às diferentes concentrações de ATP quando comparadas às células de camundongos naïves (Figura 2). Estes dados permitem inferir que a presença da infecção é um fator que leva ao aumento da sensibilidade das células fagocíticas à presença do ATP, uma vez que as células que já haviam tido um contato prévio com o contexto da infecção apresentaram maior permeabilização.

Figura 2- Permeabilização ex vivo de populações fagocíticas extraídas do baço de camudongos C57BL/6 após 4 dias de infecção pelo $P$. chabaudi.
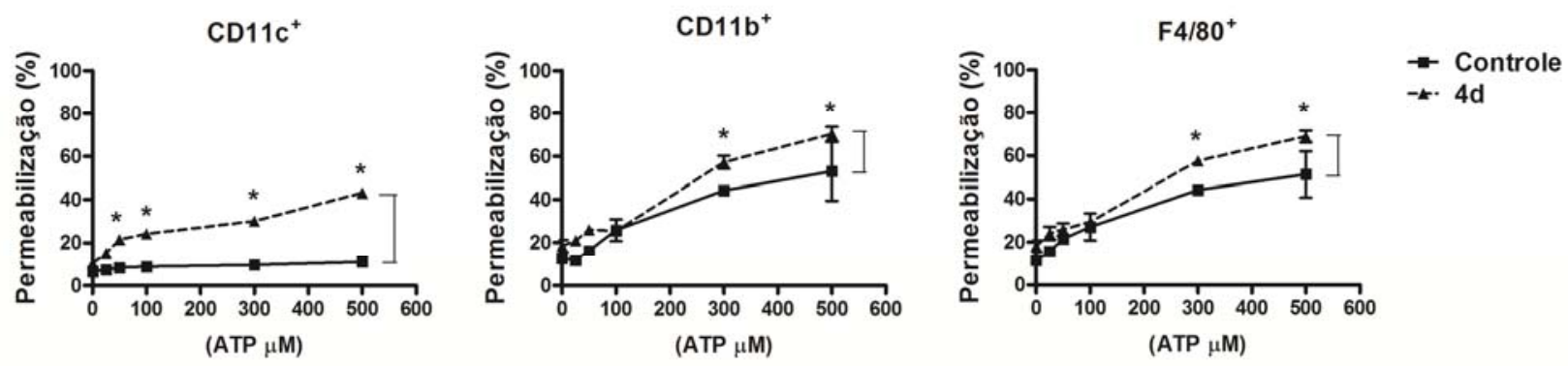

As populações $C D 11 \mathrm{C}^{+}, \mathrm{CD} 11 \mathrm{~b}^{+}$e $\mathrm{F} 4 / 80^{+}$foram extraídas do baço de camundongos não-infectados (controle) e do dia 4 pós-infecção (4d), marcadas e expostas à diferentes concentrações de ATP extracelular. A permeabilização corresponde à porcentagem de incorporação de brometo de etídio por estas células. ${ }^{*}, p<0,05$. Dados representativos de dois experimentos realizados separadamente $(n=3)$.

A fim de avaliar se a presença dos eritrócitos parasitados realmente é capaz de influenciar nesta sensibilidade dos fagócitos ao ATP, foi realizado um ensaio in vitro. Conforme apresentado na Figura 3a, a incorporação do brometo de etídio confere coloração vermelha às células, enquanto que aquelas células sem permeabilização da membrana mantêm-se verdes, já que há entrada apenas da 
laranja de acridina. A incorporação do brometo de etídio pelos macrófagos derivados da linhagem C57BL/6 ocorre de maneira dose-dependente, enquanto que os macrófagos derivados de camundongos $\mathrm{P} 2 X 7^{-1-}$ não sofrem influência da concentração de ATP extracelular, mantendo-se praticamente impermeáveis ao brometo (Figura $\mathbf{3 b}$ ). A pré-estimulação dos macrófagos derivados de animais C57BL/6 com LPS $(1 \mu \mathrm{g} / \mathrm{ml})$ ou com eritrócitos parasitados em uma proporção de 10 EP para cada macrófago foi capaz de aumentar a sensibilidade destas células quando expostas ao ATP extracelular na concentração de $1 \mathrm{mM}$ por 24 horas, diferindo significativamente ( $p<0,001$ e $p<0,01$ respectivamente) da sensibilidade das células que não foram pré-estimuladas. Além disso, a pré-estimulação com eritrócitos normais não-parasitados não exerceu o mesmo efeito, uma vez que em qualquer das concentrações de ATP extracelular, os macrófagos que não foram préestimulados apresentaram a mesma sensibilidade destes macrófagos pré-expostos aos eritrócitos não-parasitados (Figura 3b). Na concentração de $3 \mathrm{mM}$ de ATP, não houve diferença entre os macrófagos expostos a pré-estímulos e os não expostos, uma vez que todos apresentaram altas taxas de incorporação de brometo de etídio. Por fim, os macrófagos derivados dos camundongos P2X7 $7^{-1-}$ mostraram-se insensíveis ao ATP extracelular, não tendo alterações significativas na incorporação de brometo de etídio com o aumento da concentração de ATP, mesmo quando préestimulados com LPS ou eritrócitos parasitados (Figura 3c). Estes resultados indicam que a presença do parasito parece ser fundamental no aumento da sensibilidade dos macrófagos ao ATP, uma vez que o eritrócito não-parasitado não exerce tal efeito, além da dependência do receptor P2X7 neste processo de permeabilização em resposta ao ATP, já que os macrófagos deficientes para este receptor são resistentes a este fenômeno. 
(a) Imagens de microscopia de fluorescência (aumento de 200x) de macrófagos derivados de medula óssea marcados com laranja de acridina e brometo de etídio, onde as células não-permeabilizadas aparecem em verde e as permeabilizadas em vermelho após os diferentes tratamentos. (b) Quantificação da incorporação de brometo de etídio pelos macrófagos derivados de medula óssea de camundongos C57BL/6 e P2X7 $7^{-1-}$ estimulados com LPS $(1 \mu \mathrm{g} / \mathrm{ml})$, por 3 horas, ou EP e EN (10:1), por 12 horas, e expostos por 24 horas a diferentes concentrações de ATP extracelular. Macrófagos sem pré-estímulo foram utilizados como controle (CTRL). ${ }^{* *}, p<0,01 .{ }^{* * *}, p<0,001$. Dados representativos de dois experimentos independentes realizados com triplicatas. 
Figura 3 - Permeabilização in vitro de macrófagos derivados da medula óssea de camundongos C57BL/6 e P2X7 $7^{-/-}$pré-estimulados com LPS, eritrócitos parasitados (EP) ou eritrócitos não-parasitados (EN) e expostos a diferentes concentrações de ATP extracelular.

a

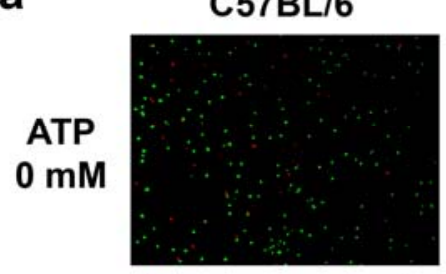

ATP

$1 \mathrm{mM}$

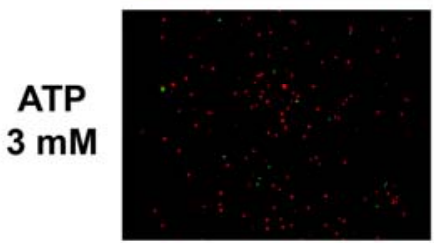

$\mathbf{P} 2 \times 7^{\text {1 }}$

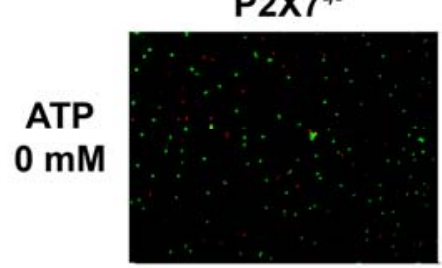

ATP

$1 \mathrm{mM}$

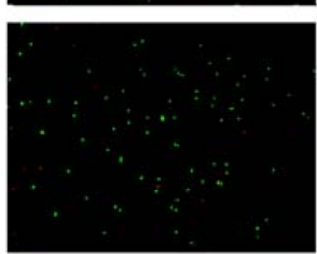

ATP

$3 \mathrm{mM}$

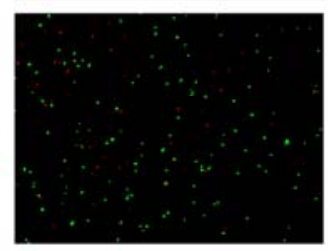

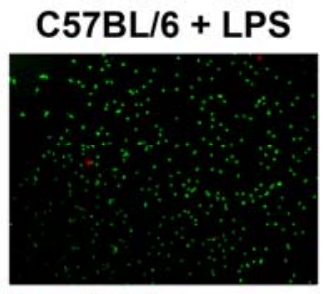
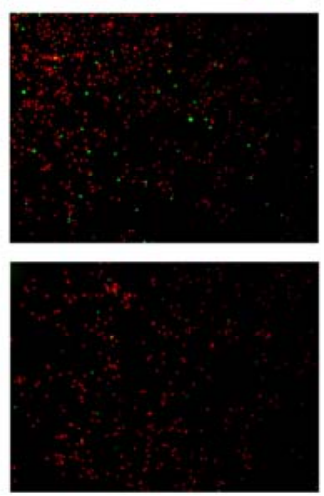

P2X7- $7^{-1}+$ LPS
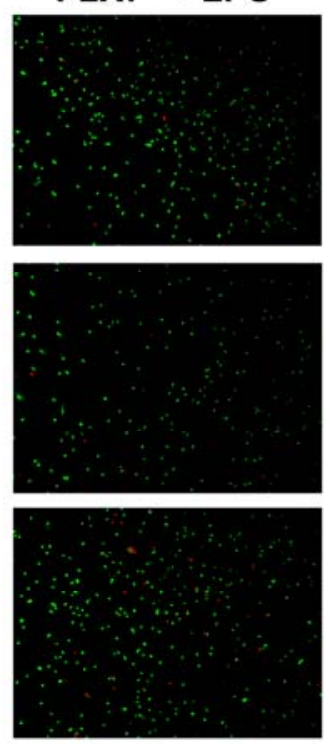
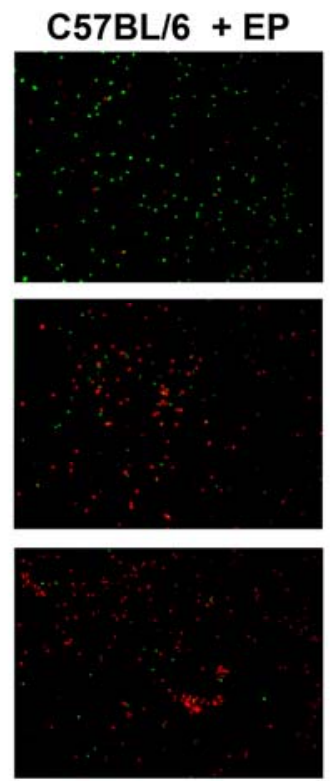

$\mathrm{P} 2 \mathrm{X}^{\text {- }}+\mathrm{EP}$
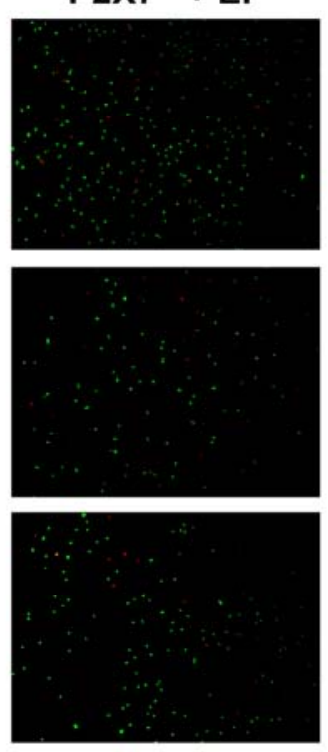

$\mathbf{P} 2 \times 7^{-1-}$
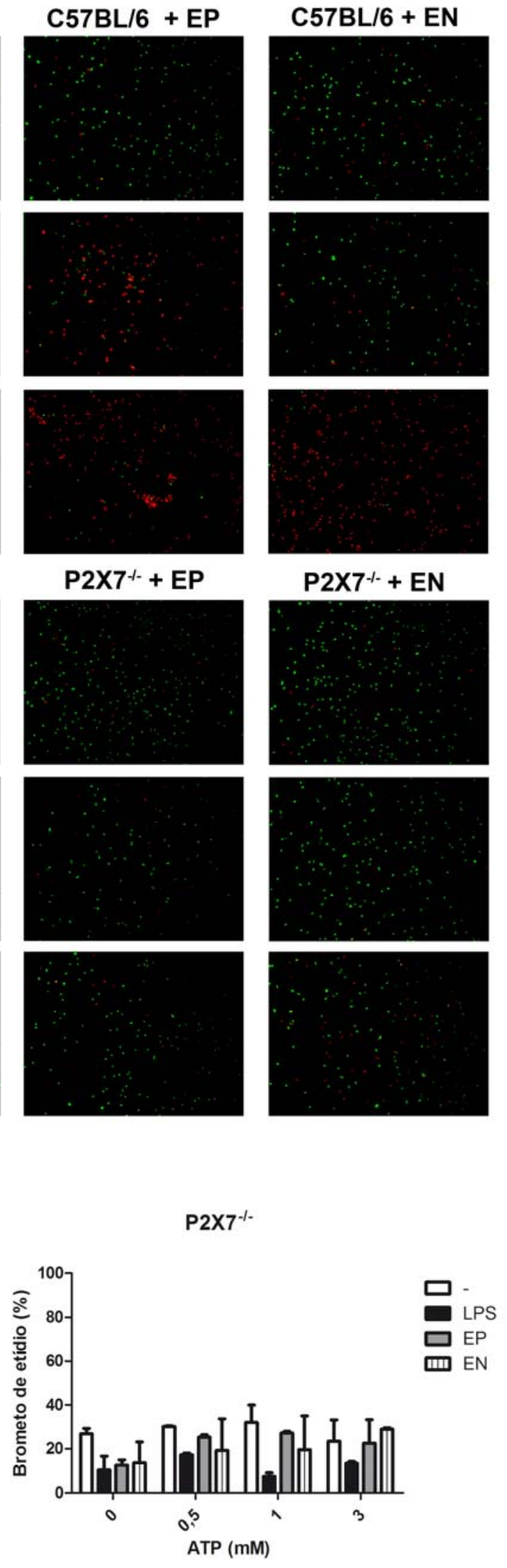

$\mathrm{P} 2 \mathrm{X7}^{-1}+\mathrm{EN}$
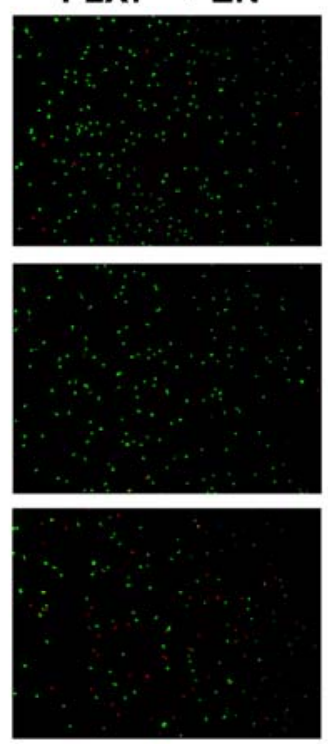

b

C57BL/6

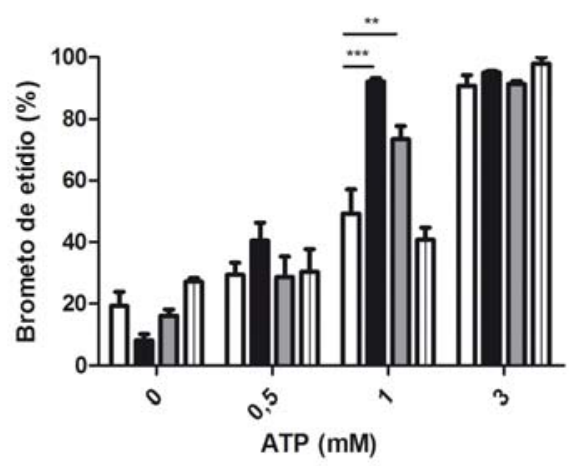




\subsection{Análise fenotípica das populações de fagócitos do baço de camundongos C57BL/6 e P2X7 ${ }^{-1-}$}

Sabendo-se da importância dos fagócitos no controle da infecção pelo $P$. chabaudi e diante dos resultados anteriores que demonstram a sensibilidade destas células à ação do ATP, buscou-se analisar as populações fagocíticas do baço de camundongos C57BL/6 e P2X7-1- a fim de avaliar se a diferença na resposta destas duas linhagens à infecção seria devida a possíveis efeitos nestas populações celulares.

Os camundongos C57BL/6 e P2X7-1- foram infectados com $10^{6}$ eritrócitos parasitados e no dia 7 pós-infecção, o qual consiste no dia de pico de parasitemia neste modelo experimental. A seguir, os baços dos animais foram extraídos para análise fenotípica. Dentre os esplenócitos, as populações selecionadas para o estudo foram aquelas classificadas de acordo com a expressão de CD11c, F4/80, CD11b, Ly6C e Ly6G, uma vez que fagócitos que expressam estes marcadores são essenciais no controle da parasitemia através da fagocitose e apresentação de antígenos. A análise realizada para o estudo fenotípico populacional está apresentada na Figura 4. Inicialmente, os linfócitos $T$ e eritrócitos foram excluídos da análise, restando, juntamente com os linfócitos $B$, as células da imunidade inata. As populações foram então classificadas pela expressão de CD11b e F4/80, e a população $\mathrm{CD} 11 \mathrm{~b}^{-} \mathrm{F} 4 / 80^{-}$foi selecionada para classificação da população $\mathrm{CD} 11 \mathrm{C}^{+}$. Dentro da população $\mathrm{CD}_{1} 1 \mathrm{~b}^{+}$, as células positivas para o marcador Ly6G, classicamente consideradas como neutrófilos [47], foram também estudadas. E por fim, também dentro de $C D 11 b^{+}$, a população com alta expressão de Ly6C e negativas para Ly6G, considerada como contendo os monócitos inflamatórios [47], também foi selecionada para o estudo.

A Figura 5a apresenta o número total de esplenócitos das duas linhagens estudadas, com o baço dos animais C57BL/6 possuindo uma celularidade significativamente maior quando comparado ao baço dos animais $\mathrm{P} 2 \times 7^{-{ }_{-}}$( $\mathrm{p}<$ 0,001). O mesmo fenômeno é observado quando são analisadas as populações

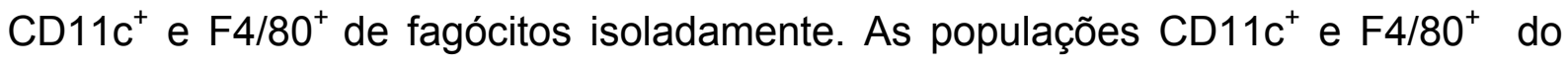
baço apresentam uma diferença significativa ( $p<0,01$ e $p<0,05$ respectivamente) em número de células entre os camundongos C57BL/6 e P2X7 ${ }^{-1-}$, com o último apresentando um número inferior de células (Figura $5 \mathbf{b}$ e $\mathbf{5 c}$ ). No entanto, para a 
população $C D 11 b^{+}$do baço não foi observada a mesma diferença significativa entre as duas linhagens de camundongos (Figura 5d). A análise das subpopulações $\mathrm{CD}_{11} \mathrm{~b}^{+}$permite observar que, embora não significativa, há uma tendência a uma diferença entre as populações $\mathrm{CD} 11 \mathrm{~b}^{+} \mathrm{Ly}_{6 \mathrm{C}^{+}}$dos animais $\mathrm{C} 57 \mathrm{BL} / 6$ e dos animais $\mathrm{P} 2 \mathrm{X}^{-1-}$, de modo semelhante às populações $\mathrm{F} 4 / 80^{+}$e $\mathrm{CD} 11 \mathrm{C}^{+}$, em que os camundongos knockouts apresentam o menor número de células (Figura 5e). No entanto, a subpopulação $\mathrm{CD} 11 \mathrm{~b}^{+} \mathrm{Ly}_{6 \mathrm{G}}{ }^{+}$comporta-se aparentemente de forma antagônica às demais, já que existe uma tendência do número de células dos animais $\mathrm{P} 2 \mathrm{X} 7^{-1-}$ ser superior ao número encontrado nos animais C57BL/6, tanto no grupo de não-infectados (0d), como no dia 7 pós-infecção (Figura 5f).

Figura 4 - Análise fenotípica utilizada na citometria de fluxo para estudopopulacional dos fagócitos do baço de animais C57BL/6 e P2X7 ${ }^{-1-}$

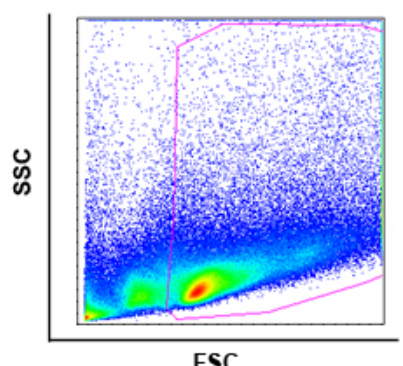

FSC

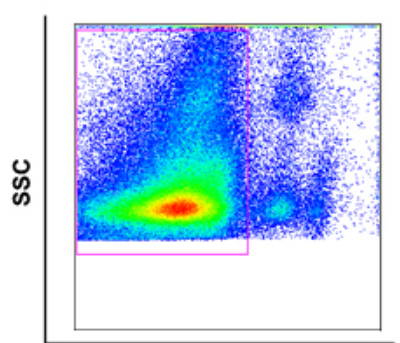

CD4 + CD8 + Ter119

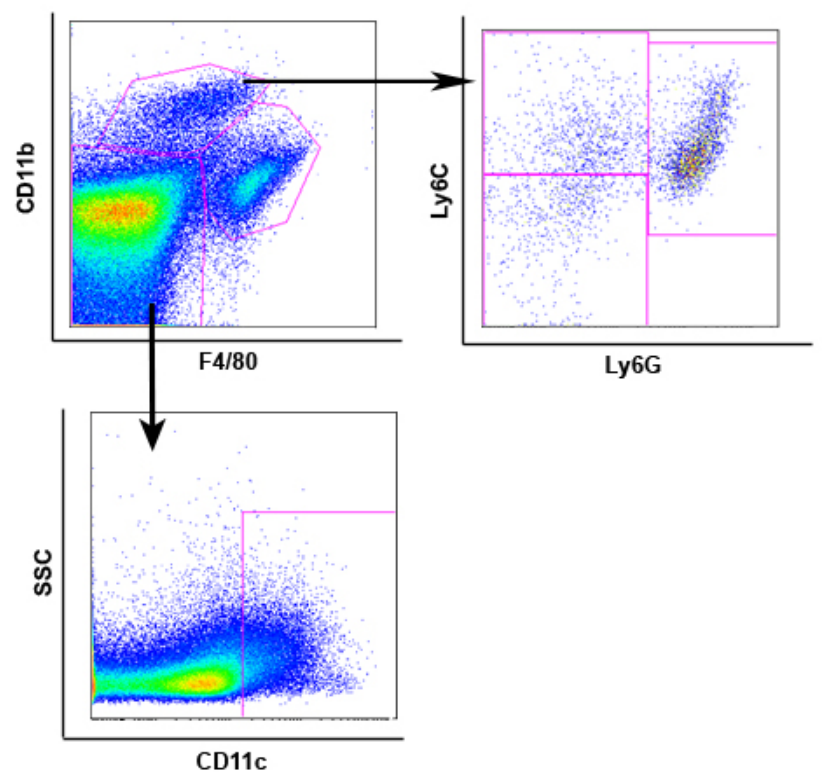

Estratégia de Gates utilizada na análise das populações CD11 $\mathrm{C}^{+}, \mathrm{F} 4 / 80^{+}, \mathrm{CD} 11 \mathrm{~b}^{+}, \mathrm{CD} 11 \mathrm{~b}^{+} \mathrm{Ly} 6 \mathrm{C}^{\text {high }} \mathrm{e}$ CD11 $\mathrm{b}^{+}$Ly6G $^{+}$.

Além da análise populacional em relação ao número de células, foi realizada também uma análise fenotípica em relação à expressão de moléculas de ativação nestas mesmas populações de fagócitos estudadas. A Figura 6 apresenta a intensidade de fluorescência que representa o nível de expressão das moléculas

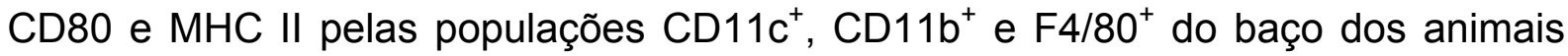
knockouts e dos C57BL/6 não-infectados e após 7 das de infecção pelo $P$. chabaudi. 
Figura 5 - Número total de esplenócitos e de fagócitos que expressam CD11c, F4/80, CD11b, Ly6C e Ly6G no baço de camundongos C57BL/6 e $\mathrm{P} 2 \times 7^{-1 /}$ controle $(0 \mathrm{~d})$ e no $7^{\circ}$ dia de infecção $(7 \mathrm{~d})$ pelo $P$. chabaudi

a

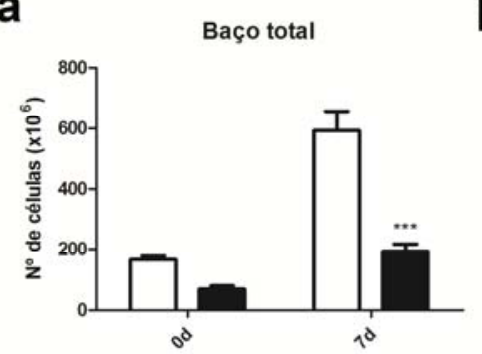

d

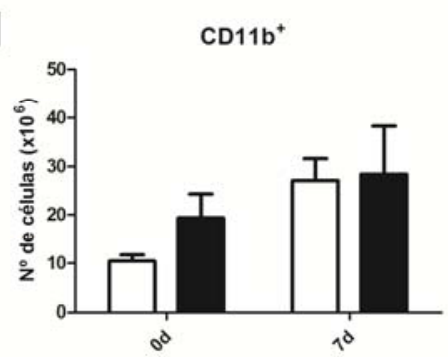

b

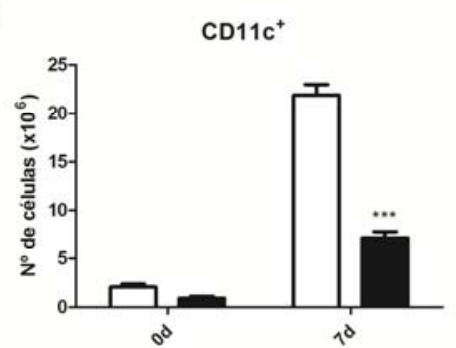

e

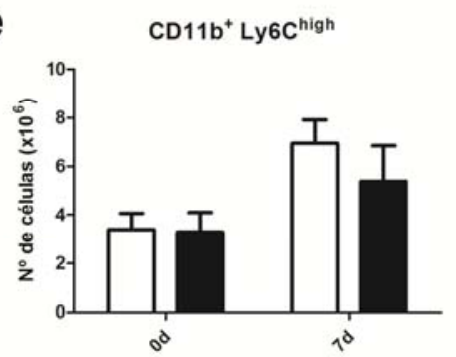

C

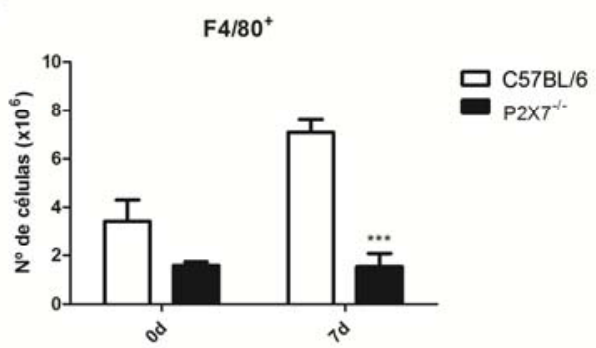

f

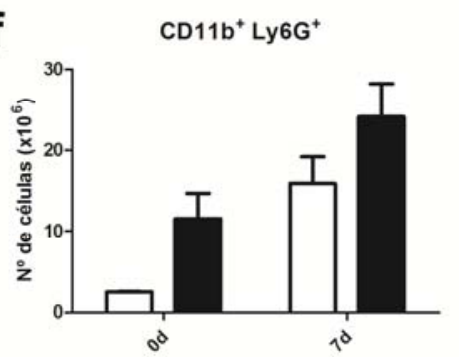

(a) Número de células totais e das populações de fagócitos que expressam CD11c (b), F4/80 (c), CD11b (d), CD11b e Ly6C (e) e CD11b e Ly6G (f) no baço de camundongos C57BL/6 e P2X7 ${ }^{-1-}$ não infectados e ao dia 7 pós-infecção. ${ }^{* * *}, p<0,001$, em relação aos números encontrados no animais C57BL/6. Dados representativos de três experimentos realizados separadamente $(n=3)$ para os números de células do baço total e das populações $C D 11 c^{+}$e $C D 11 b^{+}$. Dados representativos de dois experimentos realizados separadamente $(n=3)$ para as demais populações.

A população $C D 11 \mathrm{c}^{+}$apresentou aumento da expressão de $\mathrm{CD} 80$ no $7^{\circ}$ dia de infecção tanto no baço dos animais C57BL/6, como dos animais $\mathrm{P} 2 \times 7^{-1-}$, sem diferença nos níveis de expressão desta molécula entre as duas linhagens de camundongos. Já em relação à expressão de $\mathrm{MHC} \mathrm{II}$, a população $\mathrm{CD} 11 \mathrm{c}^{+}$manteve sua ativação basal, isto é, não houve aumento na expressão desta molécula ao longo da infecção nos animais C57BL/6 e P2X7 $7^{-1-}$ (Figura 7a). A população CD11 b ${ }^{+}$ presente no baço dos camundongos $\mathrm{P} 2 \times 7^{-/}$apresentou uma menor expressão desta molécula quando comparada à mesma população dos animais C57BL/6 no $7^{\circ}$ dia de infecção, indicando que, embora ambas as populações tenham aumentado o nível de expressão de CD80 em resposta à infecção, a população dos animais C57BL/6 se ativou mais do que a dos animais $\mathrm{P} 2 \mathrm{X} 7^{-1-}$ (Figura $7 \mathrm{~b}$ ). Em relação à expressão de MHC II, não foram encontradas diferenças entre os animais controles e os infectados, assim como entre os animais C57BL/6 e P2X7 ${ }^{-1-}$ (Figura 7b). Para a população $F 4 / 80^{+}$, os níveis de $\mathrm{CD} 80$ expressos na superfície destas células 
caíram em resposta à infecção, tanto para os animais C57BL/6, como para os P2X7I- (Figura 7c). No entanto, os valores encontrados nos animais C57BL/6 controles e no $7^{\circ}$ dia de infecção foram significativamente menores do que aqueles observados para os animais knockouts. De forma semelhante, a expressão de MHC II também se reduziu nesta população $\mathrm{F} 4 / 80^{+}$, porém, não foram observadas diferenças entre a expressão desta molécula entre as células do baço nos animais C57BL/6 e P2X7 $7^{-1-}$ (Figura 7c). Em relação à expressão de $\mathrm{MHC}$ II, portanto, não foi observada diferença significativa em nenhuma das populações estudadas entre os animais C57BL/6 e P2X7 ${ }^{-/-}$. O receptor P2X7, dessa forma, parece não influenciar na expressão de MHC II pelos fagócitos do baço, embora possa influenciar na expressão de CD80 nas diferentes populações.

Figura 6 - Expressão dos marcadores CD80 e MHC II nas populações CD11 ${ }^{+}$, $\mathrm{CD}_{11} \mathrm{~b}^{+}$e $\mathrm{F} 4 / 80^{+}$do baço dos animais C57BL/6 e P2X7 $7^{---}$nos animais não-infectados (0d) e após 7 dias de infecção $(7 \mathrm{~d})$ pelo $P$. chabaudi.

a
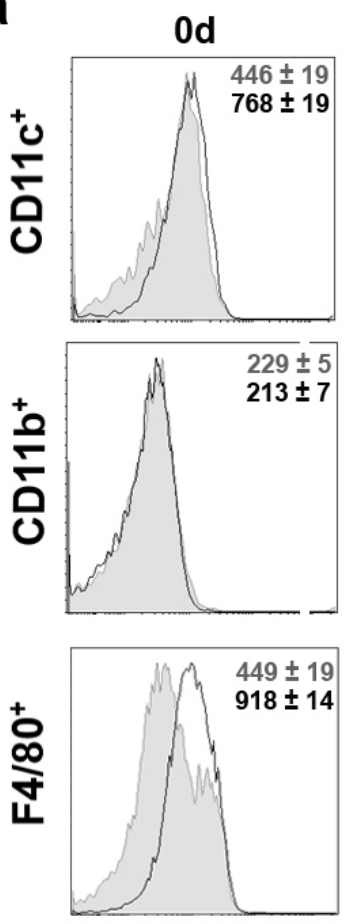

\section{CD80}

b
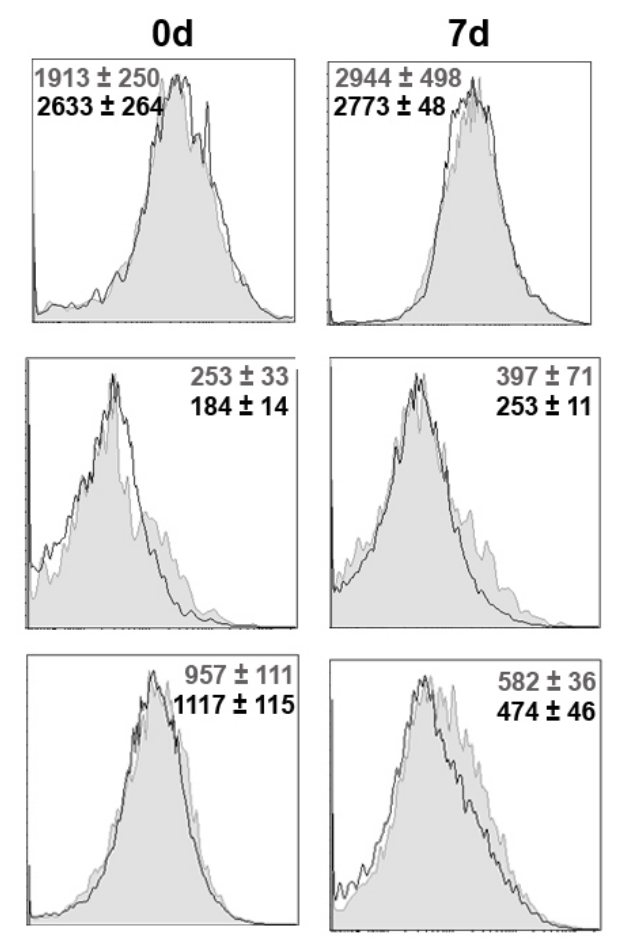

MHC II

Intensidades de fluorescência representando a expressão de CD80 (a) e MHC II (b) nas populações fagocíticas do baço de camundongos C57BL/6 e P2X7 $7^{-1-}$ não-infectados e no $7^{\circ}$ dia pós-infecção. Os números representam as médias geométricas e os desvios padrão. Dados representativos de dois experimentos realizados $(n=3)$. 
Figura 7- Expressão das moléculas de ativação CD80 e MHC II pelas células $\mathrm{CD} 11 \mathrm{c}^{+}, \mathrm{CD} 11 \mathrm{~b}^{+}$e $\mathrm{F} 4 / 80^{+}$do baço de camundongos C57BL/6 e P2X7-1não infectados (0d) e ao $7^{\circ}$ dia de infecção (7d) pelo $P$. chabaudi.

a

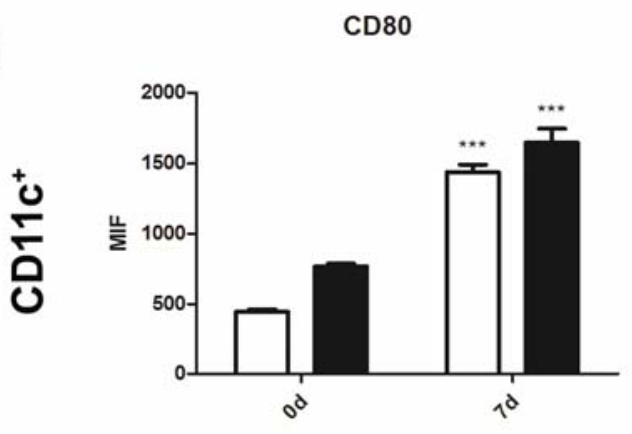

b

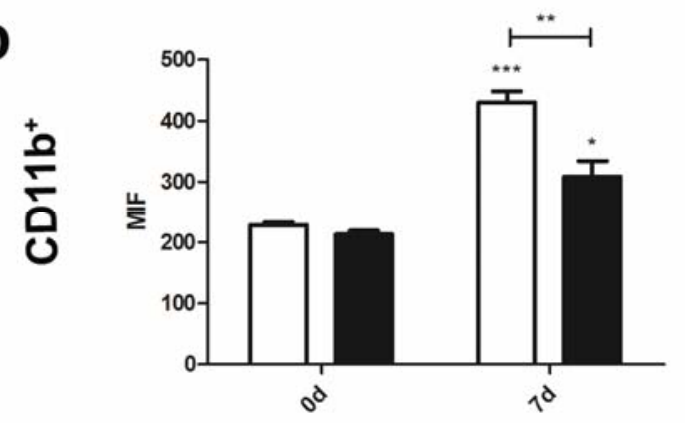

C

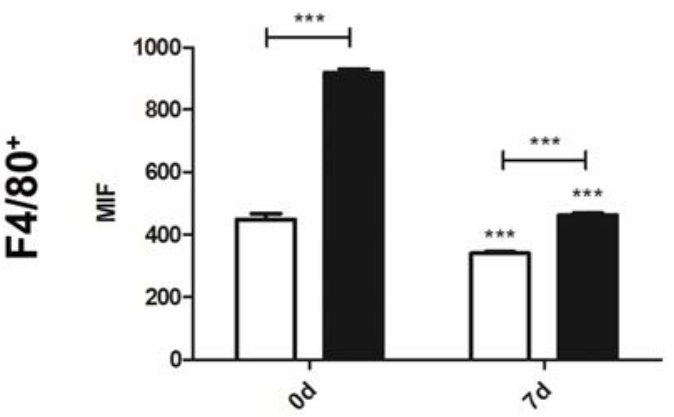

MHC II
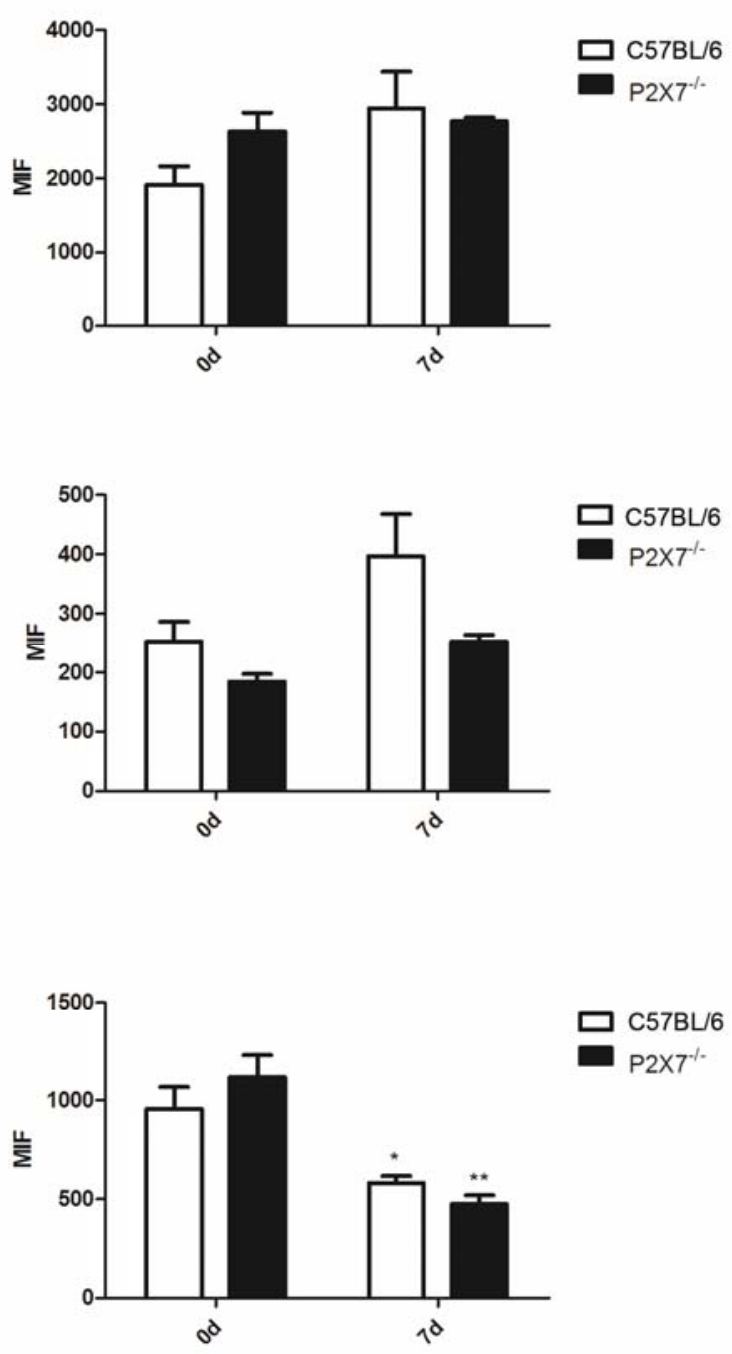

Médias geométricas das intensidades de fluorescência da expressão de CD80 e de MHC II nas células CD11 $\mathrm{c}^{+}$(a), CD11b ${ }^{+}$(b) e F4/80 ${ }^{+}$(c) do baço dos animais P2X7 ${ }^{-1-}$ e C57BL/6 controle e no dia 7 pós-infecção. ${ }^{*}, p<0,05,{ }^{* *}, p<0,01 \mathrm{e}^{* * *}, \mathrm{p}<0,001 \mathrm{em}$ relação aos números do controle não infectado (0d). Os traços indicam as estatísticas entre os grupos C57BL/6 e P2X7 $7^{-/}$. Dados representativos de dois experimentos realizados separadamente $(n=3)$.

\subsection{Produção de citocinas no baço dos camundongos $\mathrm{P} 2 \times 7^{-/}$em comparação aos animais C57BL/6}

Visto que o receptor $\mathrm{P} 2 \mathrm{X} 7$ pode influenciar no número de células fagocíticas no baço de camundongos infectados e até mesmo no estado de ativação destas células, buscou-se avaliar a influência desta molécula na produção de citocinas por estas ou outras células do sistema imune em resposta à infeç̧ão. 
Sabendo-se que o IFN-y é uma citocina fundamental na resposta à malária, principalmente na ativação de fagócitos, como os macrófagos, foi mensurada a concentração desta citocina na cultura de fagócitos totais com células $\mathrm{T} \mathrm{CD} 4^{+}$do baço de animais do $7^{\circ}$ dia de infecção, na presença e na ausência do estímulo específico dos eritrócitos parasitados, após 72 horas de cultivo.

Conforme apresentado na Figura 8, a produção de IFN- $\gamma$, na presença dos eritrócitos parasitados, é significativamente maior na cultura das células extraídas do baço dos camundongos C57BL/6 em comparação aquelas obtidas dos knockouts para o receptor $\mathrm{P} 2 \mathrm{X} 7$. Analisando o número de células produtoras de IFN-ץ no baço destes animais, observa-se que as células $\mathrm{T} C D 4^{+}$produzem esta citocina no $7^{\circ}$ dia de infecção (Figura 9a) e que o número de células $\mathrm{T} \mathrm{CD4}^{+}$produtoras de IFN-y é significativamente menor nos animais $\mathrm{P} 2 \mathrm{X} 7^{-1-}$ do que nos animais C57BL/6 (Figura 9c), embora não tenha sido encontrada diferença na frequência destas células no baço dos animais (Figura $9 b$ ).

Figura 8 - Produção de IFN-y na cultura de fagócitos com células T CD4 ${ }^{+}$extraídas do baço de animais C57BL/6 e P2X7 $7^{-1-}$ não-infectados (Ctrl) e ao $7^{\circ}$ dia de infecção (7d) na presença ou não de eritrócitos parasitados (EP).

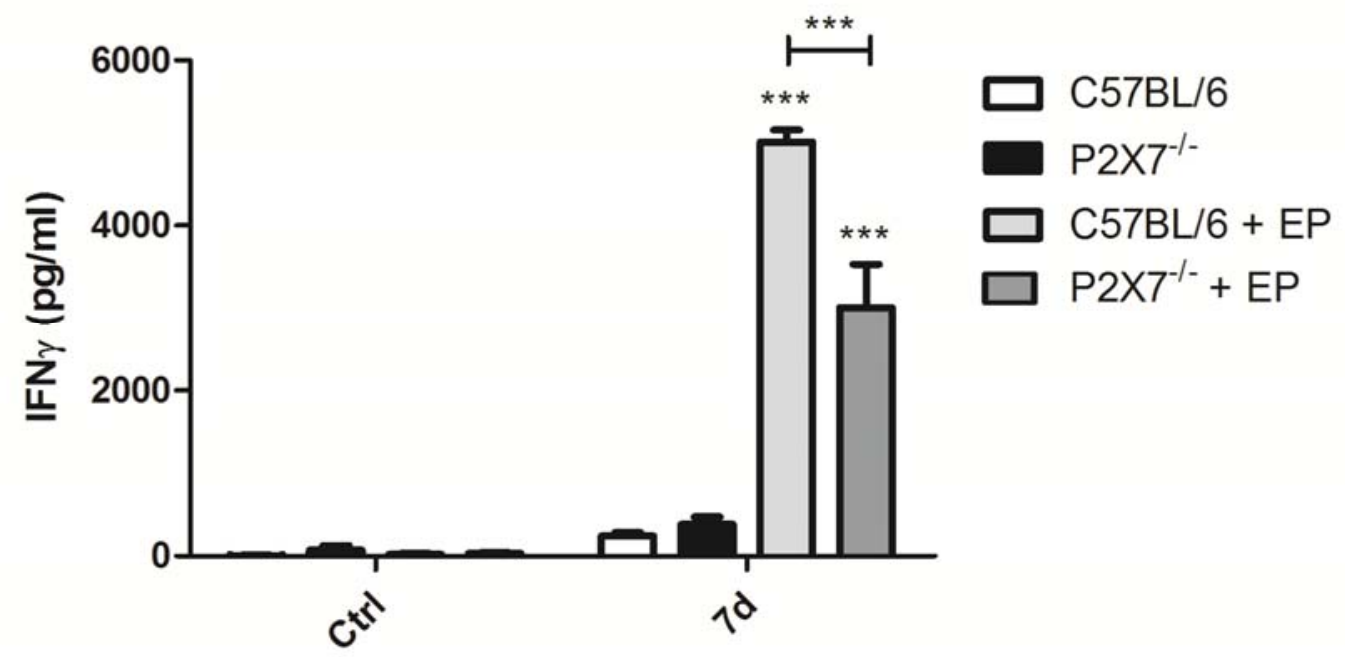

Concentração de IFN-y no sobrenadante da cultura de 72 horas de fagócitos e células T CD4 ${ }^{+}$ isolados do baço de camundongos $\mathrm{C} 57 \mathrm{BL} / 6$ e P2X7 $7^{-/-}$na presença ou não do estímulo de EP. ${ }^{* * *}, \mathrm{p}<$ 0,001 em relação aos dados do controle (Ctrl). A barra indica a diferença entre os dados do C57BL/6 + EP e P2X7 $7^{-1-}+E P$. Dados representativos de dois experimentos realizados separadamente $(n=3)$.

Além da produção de IFN-y pelos linfócitos, foi analisada a produção de citocinas pró e anti-inflamatórias, como TNF- $\alpha$ e IL-10, pelos próprios fagócitos no $7^{\circ}$ dia de infecção, a fim de avaliar o número de células fagocíticas produtoras destas 
citocinas. A produção de $\mathrm{IL}-10$ pelos fagócitos $\mathrm{CD} 11 \mathrm{c}^{+}$e $\mathrm{F} 4 / 80^{+}$pode ser observada no dia 7 pós-infecção pelo $P$. chabaudi tanto nos animais C57BL/6, como nos knockouts (Figuras 9a e 9d), sem diferenças significativas na frequência destas células (Figura 9b e 9e). No entanto, o número de células $\mathrm{CD} 11 \mathrm{c}^{+}$e $\mathrm{F} 4 / 80^{+}$ produtoras de IL-10 é significativamente menor nos camundongos $\mathrm{P} 2 \mathrm{X}^{-/-}$(Figuras $10 \mathrm{c}$ e 10f), indicando que a redução no número total de células implicou também na diminuição da quantidade de células produtoras de IL-10, possivelmente diminuindo a produção desta citocina nos animais $\mathrm{P} 2 \mathrm{X}^{-{ }^{-1}}$. Quanto à produção de TNF- $\alpha$, o mesmo fenômeno foi observado para a população de células $C D 11 c^{+}$do baço destes animais no $7^{\circ}$ dia de infecção, embora a detecção intracelular desta citocina nesta população tenha sido baixa (Figura 11a). As células $C D 11 c^{+}$produtoras de TNF- $\alpha$ dos camundongos C57BL/6 apresentaram-se tanto em maior frequência, como em maior número absoluto em comparação às células dos animais $\mathrm{P} 2 \times 7^{-1-}$ (Figuras 11b e 11c). Já em relação à produção $F 4 / 80^{+}$, a detecção intracelular da produção de TNF- $\alpha$ também foi baixa (Figura 11d) e não foram encontradas diferenças na frequência, nem no número de células $\mathrm{F} 4 / 80^{+} \mathrm{TNF}-\alpha^{+}$entre os camundongos C57BL/6 e P2X7 $7^{-1-}$ (Figuras 11e e 11f).

Figura 9 - Produção de IFN-y pelas células T CD4 ${ }^{+}$no baço de animais C57BL/6 e $\mathrm{P} 2 X 7^{-1 /}$ no dia 7 pós-infecção pelo $P$. chabaudi

a

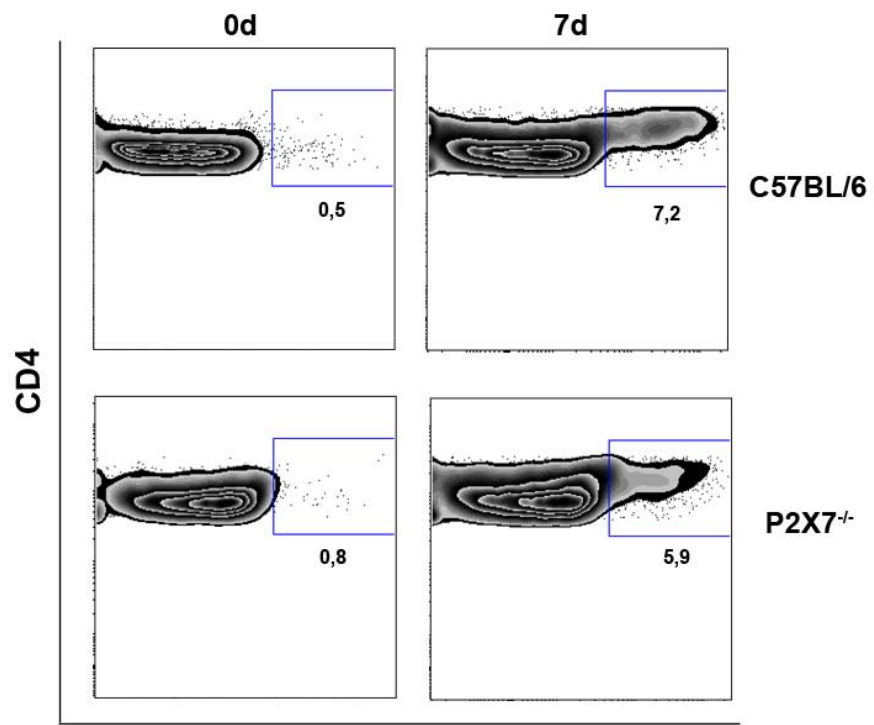

b

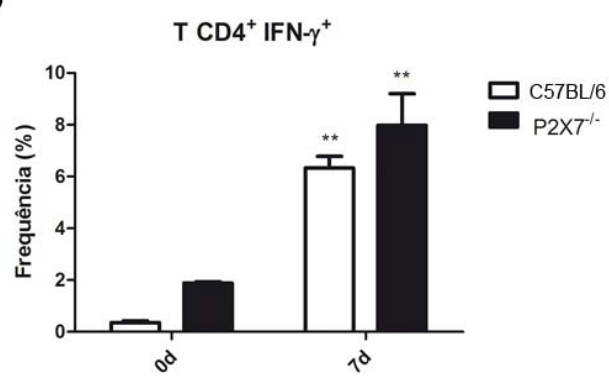

C

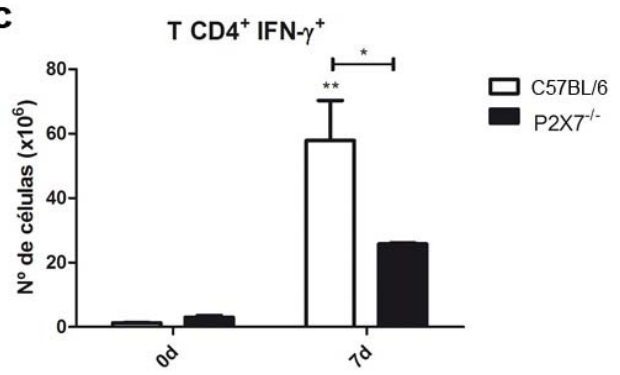

(a) Detecção intracelular da produção de IFN-y pelas células $\mathrm{T} C D 4^{+}$. Frequência (b) e número de células (c) T CD4 ${ }^{+}$IFN-Y ${ }^{+}$no baço dos animais C57BL/6 e P2X7 ${ }^{-/-}$não-infectados (0d) e com 7 dias de infecção. ${ }^{* *}, p<0,01$ em relação aos números do controle $(0 \mathrm{~d})$. A barra indica a diferença entre $\mathrm{C} 57 \mathrm{BL} / 6$ e $\mathrm{P} 2 \mathrm{X}^{-1 /}$. Dados representativos de um experimento realizado $(\mathrm{n}=3)$. 
Plots representando a detecção intracelular de IL-10 nas células $C D 11 c^{+}$nos animais não-infectados (0d) e ao $7^{\circ}$ dia de infecção (7d) (a). Frequência (b) e número de células (c) $\mathrm{CD} 11 \mathrm{c}^{+} \mathrm{IL}-10^{+}$no baço dos animais C57BL/6 e P2X7 $7^{-1}$. Plots representando a detecção intracelular de IL-10 nas células $\mathrm{F} 4 / 80^{+}$(d). Frequência (e) e número de células (f) $\mathrm{F} 4 / 80^{+} \mathrm{IL}-10^{+}$no baço dos animais $\mathrm{C} 57 \mathrm{BL} / 6$ e $\mathrm{P} 2 X 7^{-/-}$não-infectados e com 7 dias de infecção. ${ }^{* *}, p<0,01 e^{* * *}, p<0,001$ em relação aos números dos camundongos não-infectados (0d). As barras indicam a diferença entre C57BL/6 e P2X7 ${ }^{-1 /}$. Dados representativos de um experimento realizado $(n=3)$. 
Tais resultados sugerem que haja uma resposta deficiente dos camundongos $\mathrm{P} 2 \mathrm{X} 7^{-1-}$ em relação à produção das citocinas IFN- $\mathrm{\gamma}, \mathrm{IL}-10$ e TNF- $\alpha$, uma vez que foram observadas menores concentrações de IFN-ץ na cultura de células extraídas do baço destes animais, além da presença de menos células produtoras das três citocinas referidas, com exceção das células F4/80 produtoras de TNF- $\alpha$. As citocinas avaliadas podem exercer efeito sobre os fagócitos (IFN- $\mathrm{\gamma}$ ) ou serem produzidas pelos mesmos (IL-10 e TNF- $\alpha$ ), de modo que a ativação das populações fagocíticas pode estar sendo deficiente e, consequentemente, a produção de citocinas subsequente também pode ser atingida, produzindo uma resposta efetora falha.

Figura 10 - Produção de IL-10 pelas populações fagocíticas $\mathrm{CD} 11 \mathrm{c}^{+}$e $\mathrm{F} 4 / 80^{+}$do baço de camundongos $\mathrm{C} 57 \mathrm{BL} / 6$ e $\mathrm{P} 2 \times 7^{-/-}$no $7^{\circ}$ dia de infecção pelo P. chabaudi

a

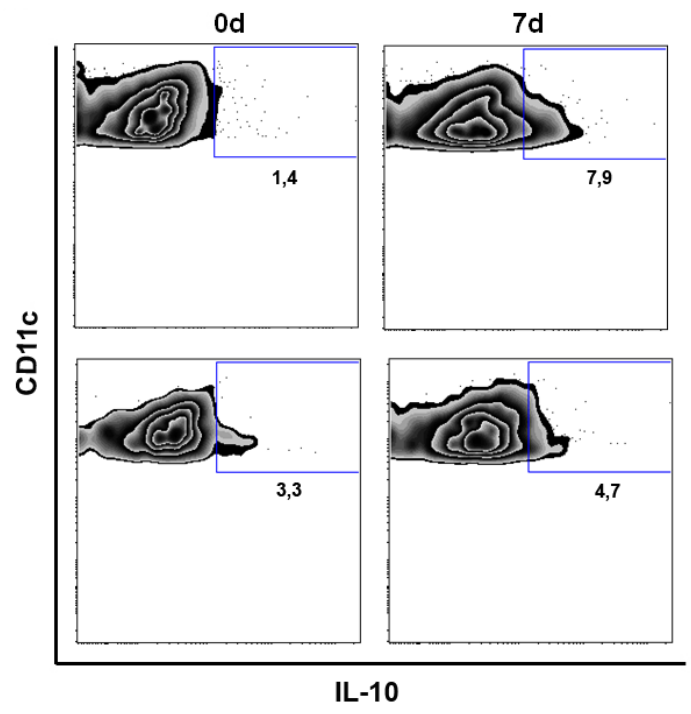

d

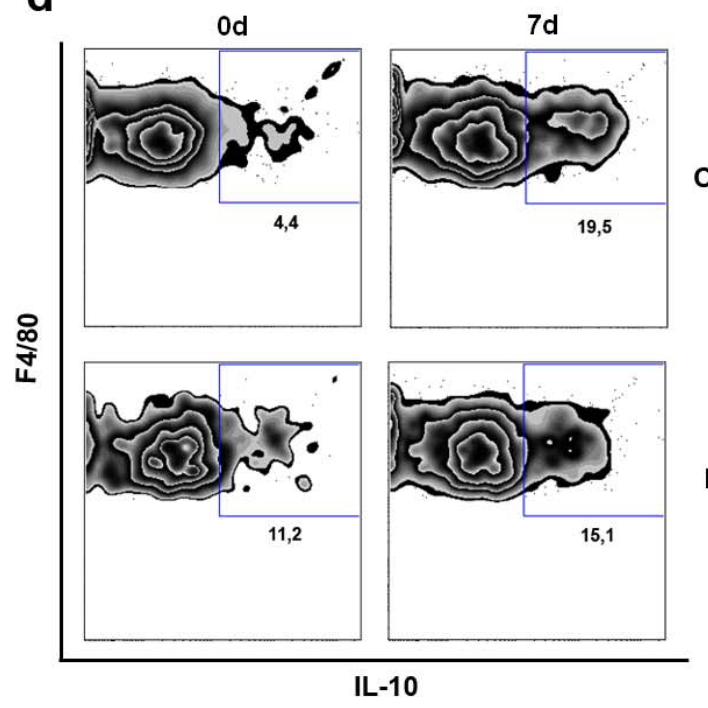

b

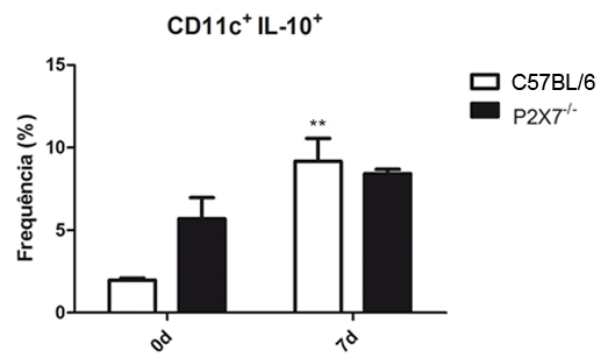

C

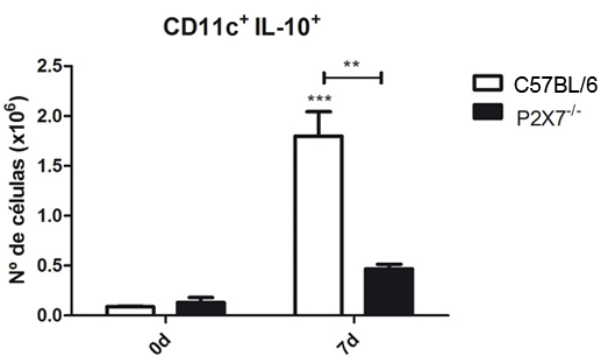

e

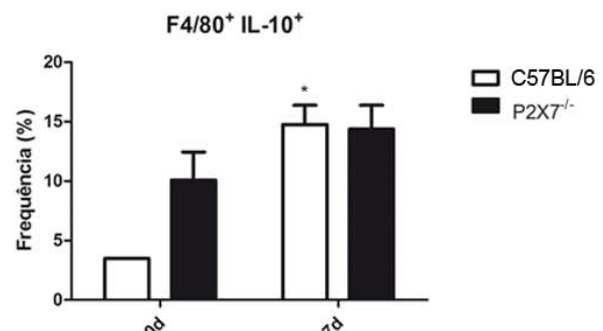

f

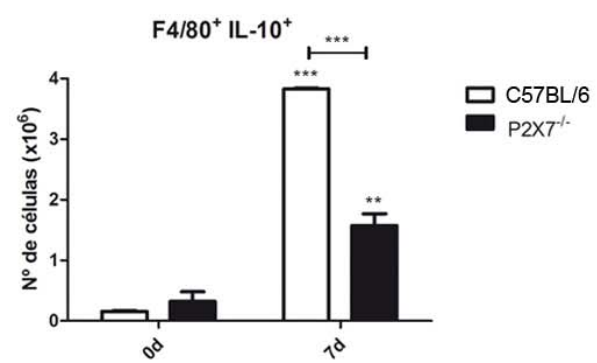


Figura 11 - Produção de TNF- $\alpha$ pelas populações fagocíticas $C D 11 c^{+}$e F4/80 $0^{+}$do baço de camundongos C57BL/6 e P2X7 $7^{-/-}$no $7^{\circ}$ dia de infecção pelo $P$. chabaudi

a

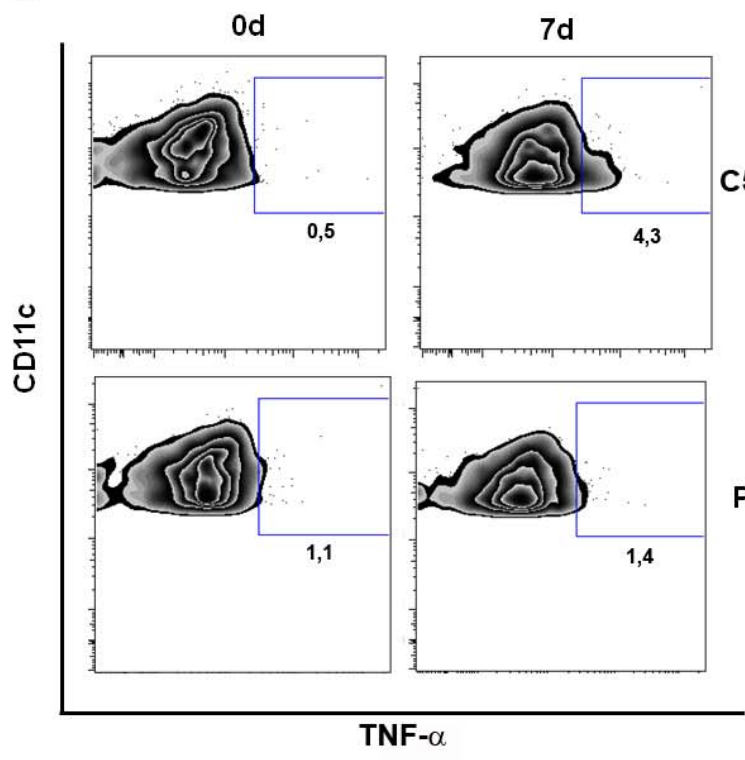

d

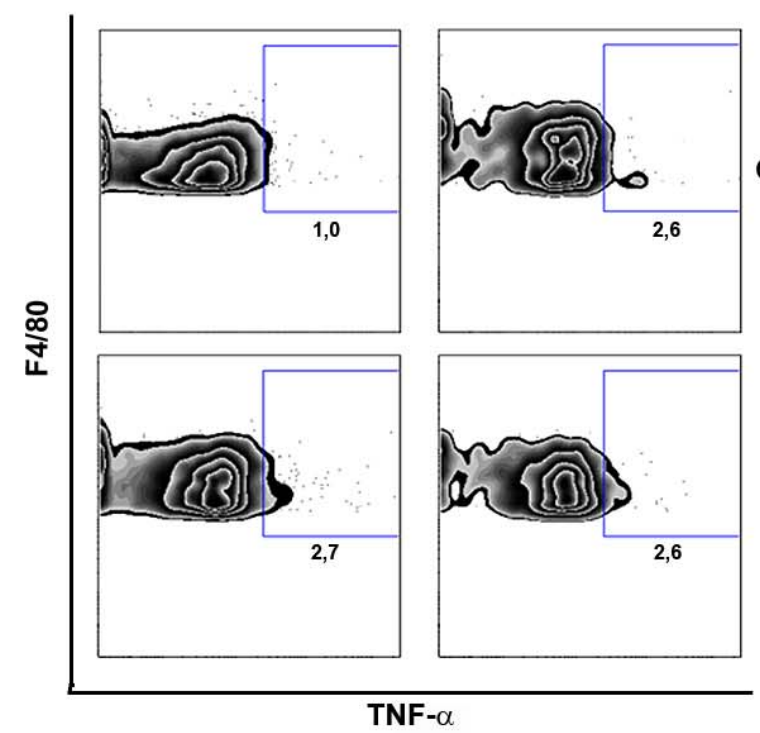

b

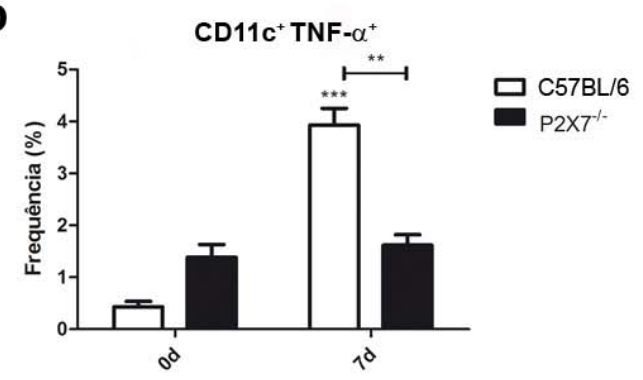

C

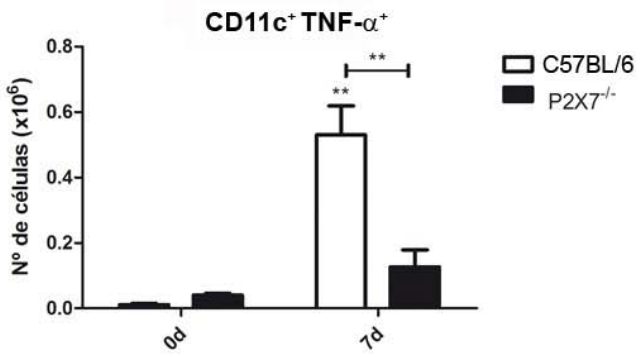

e

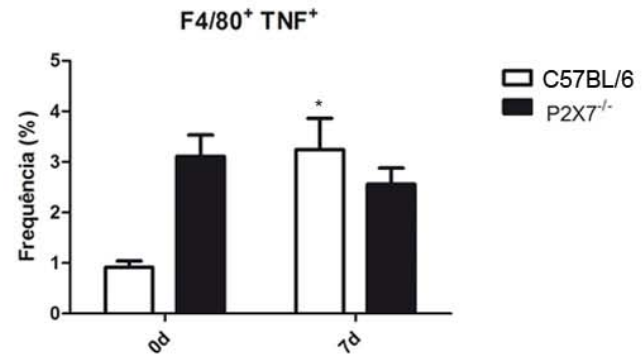

f

$\mathrm{P} 2 \times 7^{-1-}$

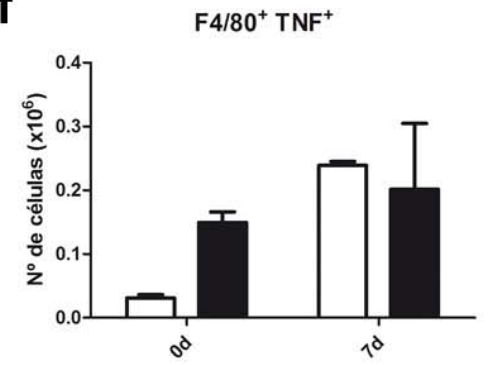

Plots representando a detecção intracelular de TNF- $\alpha$ nas células $C D 11 c^{+}$nos animais não-infectados (0d) e ao $7^{\circ}$ dia de infecção (7d) (a). Frequência (b) e número de células (c) CD11 $c^{+}$TNF- $\alpha^{+}$no baço dos animais C57BL/6 e P2X7 $7^{-1}$. Plots representando a detecção intracelular de TNF- $\alpha$ nas células $\mathrm{F} 4 / 80^{+}$(d). Frequência (e) e número de células (f) $\mathrm{F} 4 / 80^{+}$TNF- $\alpha^{+}$no baço dos animais C57BL/6 e $\mathrm{P} 2 X 7^{-/-}$não-infectados e com 7 dias de infecção. ${ }^{* \star}, p<0,01 e^{* \star *}, p<0,001$ em relação aos números dos camundongos não-infectados (0d). As barras indicam as diferenças entre C57BL/6 e P2X7 $7^{-1-}$. Dados representativos de um experimento realizado $(n=3)$. 


\subsection{Análise fenotípica das populações de células que infiltram o fígado dos camundongos C57BL/6 e P2X7 $7^{-1-}$ em resposta à infecção pelo $P$. chabaudi}

Apesar do baço ser o órgão linfoide fundamental na resposta à malária, estudos anteriores realizados pelo nosso grupo de pesquisa observaram grandes diferenças na necrose hepática decorrente da malária experimental entre os animais C57BL/6 e $\mathrm{P} 2 \mathrm{X}^{-1}$. A fim de avaliar a reposta imune no fígado na malária desenvolvida pelos animais $\mathrm{C} 57 \mathrm{BL} / 6$ e $\mathrm{P} 2 \mathrm{X} 7^{-1-}$, analisamos as populações de células do sistema imunológico presentes neste órgão destas duas linhagens de camundongos.

Na Figura 12 pode-se observar a análise fenotípica realizada para estudo das populações de linfócitos $T C D 4^{+}$e $T C D 8^{+}$e de fagócitos $\mathrm{F} 4 / 80^{+}, C D 11 b^{+} \mathrm{Ly}_{6 C^{+}} \mathrm{e}$ $\mathrm{CD}_{11 \mathrm{~b}^{+} \mathrm{Ly} \mathrm{G}^{+} \text {no fígado dos animais C57BL/6 e P2X7 }}{ }^{-1}$ não-infectados e no dia 7 pós-infecção pelo $P$. chabaudi. A Figura 12 ilustra o menor número de células encontrado na quantificação destas populações no fígado e apresentado em gráficos na Figura 13. Assim como foi visto no baço, o número total de células do fígado dos animais $\mathrm{P} 2 \times 7^{-1-}$ é significativamente menor do que o número de células encontrado no fígado dos animais C57BL/6 no $7^{\circ}$ dia pós-infecção (Figura 13a). As populações $\mathrm{CD}^{+}$e $\mathrm{F} 4 / 80^{+}$seguiram o mesmo comportamento, apresentando-se em números significativamente menores no fígado dos animais knockouts 7 dias após a infecção pelo $P$. chabaudi (Figuras 13b e 13d). Embora não tenha sido encontrada significância estatística, as populações $C D 8^{+}$e $C D 11 b^{+}$Ly6 $C^{\text {high }}$ apresentaram uma tendência a possuir menor número de células no fígado dos animais $\mathrm{P} 2 \mathrm{X} 7^{-1-} \mathrm{em}$ relação aos C57BL/6, no $7^{\circ}$ dia pós-infecção (Figuras 13c e 13e). A população $\mathrm{CD} 11 \mathrm{~b}^{+} \mathrm{Ly}_{6 \mathrm{G}}{ }^{+}$apresentou um comportamento contrário às demais populações, com os animais $\mathrm{P} 2 \mathrm{X}^{-/-}$possuindo maior número de células no fígado dos animais na ausência da infecção, fenômeno que também havia sido observado no baço, e sem uma diferença no número de células no dia 7 pós-infecção (Figura 13f). A fenotipagem das populações celulares do fígado obteve resultados que reproduziram o padrão de menor número de células visto também no baço dos animais $\mathrm{P} 2 \mathrm{X} 7^{-{ }^{-}}$, com exceção da população $\mathrm{CD} 11 \mathrm{~b}^{+} \mathrm{Ly}_{6 \mathrm{G}}{ }^{+}$. 
Figura 12 - Análise fenotípica utilizada na citometria de fluxo para estudo populacional dos linfócitos e fagócitos do fígado de animais C57BL/6 e $\mathrm{P} 2 \times 7^{-1-}$ não-infectados $(0 \mathrm{~d})$ e no $7^{\circ}$ dia pós-infecção pelo $P$. chabaudi

a

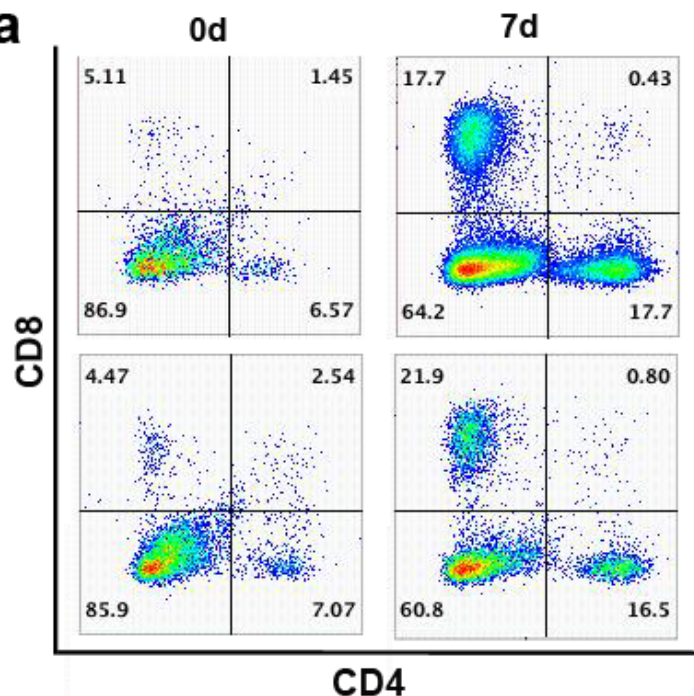

C

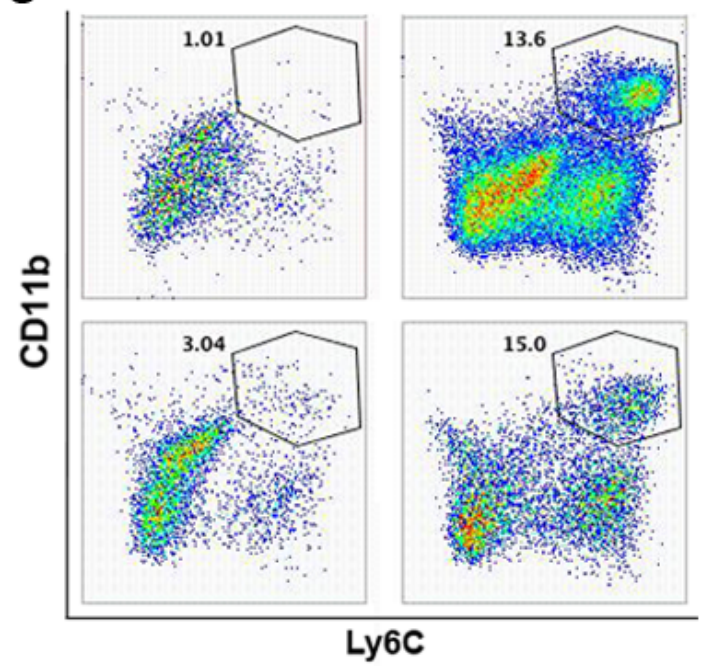

b
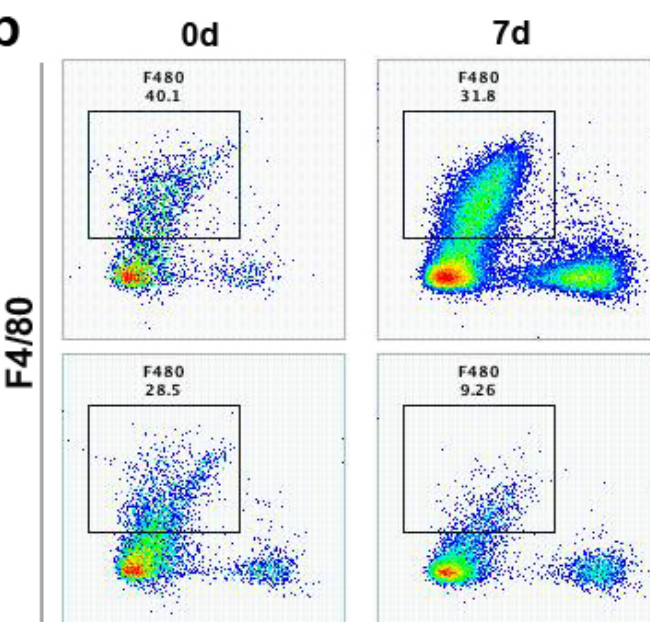

C57BL/6

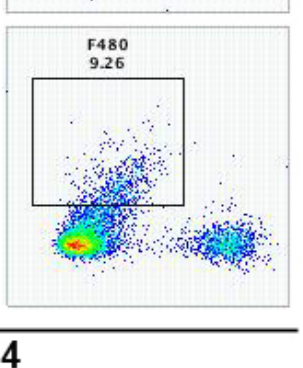

$\mathbf{P} 2 \times 7^{-1-}$

d

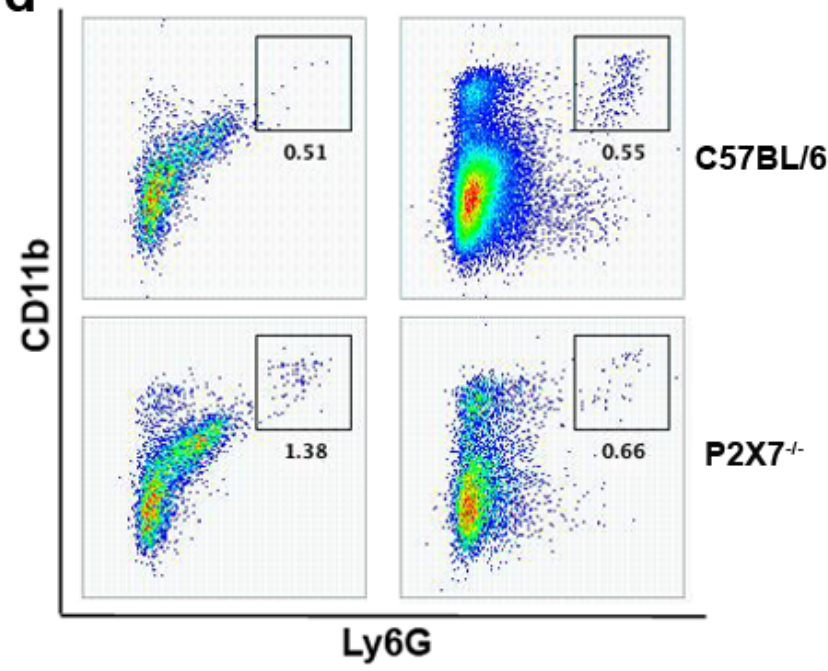

Gates utilizados para análise das populações de células que expressavam os marcadores de linfócitos CD4 e CD8 (a), o marcador de fagócitos F4/80 (b), e que expressavam concomitantemente os marcadores de fagócitos CD11b e Ly6C (c) e CD11b e Ly6G (d) nos animais C57BL/6 e P2X7 $7^{-1-}$ não-infectados e após 7 dias de infecção. Os números representam as frequências destas populações. Dados representativos de um experimento realizado $(n=3)$. 
Figura 13 - Número de células totais, de linfócitos que expressam CD4 e CD8, e de fagócitos que expressam F4/80, CD11b, Ly6C e Ly6G no fígado de camundongos $\mathrm{C} 57 \mathrm{BL} / 6$ e P2X7 $7^{-1-}$ controle (0d) e no $7^{\circ}$ dia de infecção (7d) pelo P. chabaudi

a

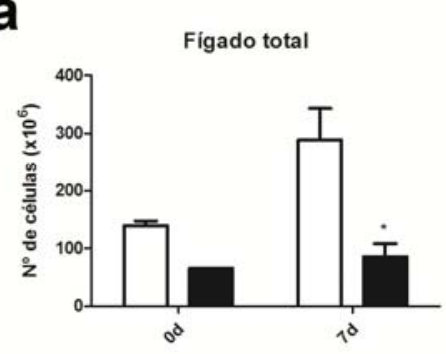

d

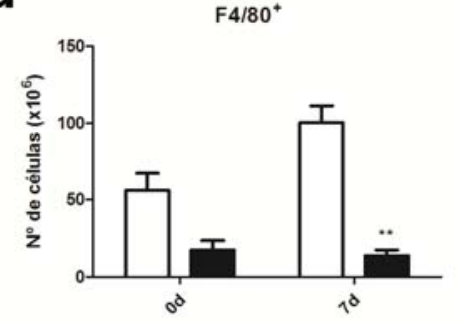

b

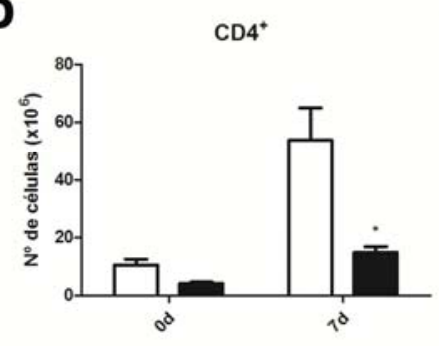

e

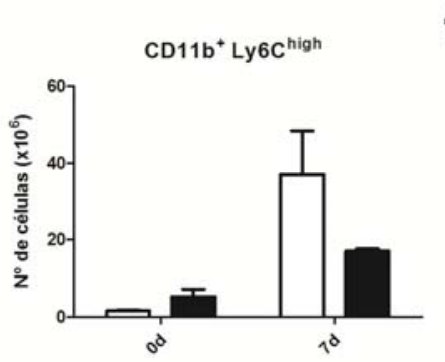

C

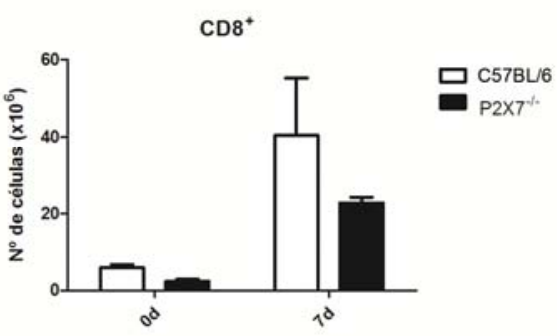

f

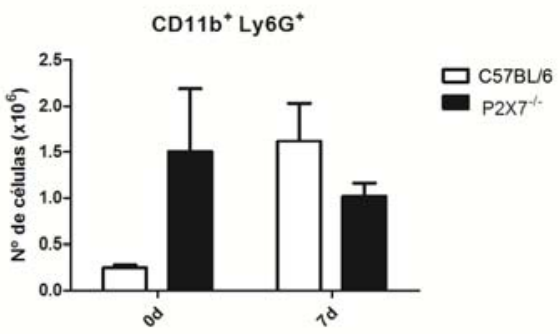

Número de células totais (a), de linfócitos $\mathrm{T} \mathrm{CD}^{+}$(b), $\mathrm{T} \mathrm{CD}^{+}$(c), e das populações de fagócitos $\mathrm{F} 4 / 80^{+}$(d), CD11 ${ }^{+}$Ly6C high (e) e CD11 $\mathrm{b}^{+} \mathrm{Ly} 6 \mathrm{G}^{+}$(f) no fígado de camundongos C57BL/6 e P2X7 $7^{-1-}$ não infectados e ao dia 7 pós-infecção. ${ }^{*}, p<0,05 e^{* *}, p<0,01$, em relação aos números do C57BL/6. Dados representativos de um experimento realizado $(n=3)$. 


\section{DISCUSSÃo}

A fim de avaliar a importância do receptor P2X7 no modelo experimental de malária, foi inicialmente realizada uma descrição das manifestações clínicas da doença desenvolvida pelos camundongos knockouts para este receptor frente à infecção pelo $P$. chabaudi. Esta é a primeira vez que é realizada uma descrição destas manifestações no curso da infecção por $P$. chabaudi em camundongos $\mathrm{P} 2 \mathrm{X}^{-/ 2}$, comparando-os aos C57BL/6, para os quais já é descrita a queda da temperatura, peso e concentração de hemoglobina no sangue após o pico de parasitemia [48]. Os camundongos knockouts, portanto, mostraram-se mais suscetíveis à infecção, que chegou a ser letal para $80 \%$ dos animais, apresentando maiores parasitemias e manifestações clínicas, como a queda mais acentuada de peso e temperatura corporais, assim como da concentração de hemoglobina sérica. De forma semelhante, os camundongos $\mathrm{P} 2 \mathrm{X} 7^{-1 /}$ são mais suscetíveis à toxoplasmose aguda, perdendo peso de forma mais rápida e mais acentuada do que os animais C57BL/6 [49], exemplificando um papel importante do receptor P2X7 na suscetibilidade a mais uma doença parasitária. Além disso, acredita-se que mutações que levem à perda de função do receptor P2X7 aumentam a suscetibilidade de seres humanos a infecções pela bactéria intracelular Chlamydia trachomatis, já tendo sido demonstrado que macrófagos murinos deficientes para o P2X7 apresentam falha na eliminação desta bactéria [50].

Sabe-se que grande parte das manifestações clínicas e complicações da malária são devidas principalmente a fatores decorrentes da resposta imunológica, a qual também é fundamental para a proteção contra a doença [22]. Além disso, como já foi citado anteriormente, praticamente todas as células do sistema imune expressam o receptor $\mathrm{P} 2 \mathrm{X} 7$ em sua superfície [24], o que sugere que estas células sejam, de alguma forma, vulneráveis às diferentes ações do ATP liberado pelo eritrócito. A Figura 3 mostrou que a permeabilização in vitro de macrófagos derivados de medula óssea pelo ATP extracelular é dependente do P2X7, uma vez que os macrófagos de camundongos $\mathrm{P} 2 \mathrm{X} 7^{-/-}$mantiveram sua permeabilidade, mesmo quando expostos a concentrações muito altas de ATP, enquanto que os macrófagos derivados de camundongos C57BL/6 apresentaram altas taxas de incorporação de brometo de etídio, demonstrando uma permeabilização dosedependente ao ATP. O aumento da sensibilidade ao ATP extracelular causado pela 
pré-exposição dos macrófagos ao LPS, agonista de TLR4, já havia sido descrito por Le Freuve et al. [51], corroborando com os dados aqui apresentados em relação ao LPS. O mesmo aumento foi observado na presença dos eritrócitos parasitados, indicando que os macrófagos que entram em contato com o parasito são mais sensíveis à sinalização do ATP do que aqueles que entraram em contato com eritrócitos não-infectados. Vale lembrar que foi observado pelo nosso grupo de pesquisa que a concentração sérica de ATP extracelular aumenta após o rompimento dos eritrócitos e liberação dos merozoítas (Salles et al., manuscrito em preparação), o que sugere que este ATP pode, portanto, exercer efeitos importantes nos fagócitos presentes na resposta à infecção. Para verificar se os fagócitos que entraram em contato com os eritrócitos parasitados no contexto da infecção no camundongo, foi realizado o ensaio de permeabilização ex vivo, o qual apresentou resultados que corroboraram com o aumento da sensibilidade das células fagocíticas estimuladas com o parasito ao ATP. Já foi descrito o aumento da expressão de $\mathrm{P} 2 \mathrm{X} 7$ em monócitos em resposta a estímulos pró-inflamatórios, como IFN- $\gamma$, TNF- $\alpha$ e ao próprio sinal do LPS [52]. Mais estudos são necessários para determinar se a causa desta maior suscetibilidade ao ATP se deve ao aumento da expressão do receptor P2X7 ou a outros fatores, no entanto, os resultados apresentados permitem concluir que a infecção pelo $P$. chabaudi torna as células fagocíticas mais sensíveis ao ATP presente no meio extracelular, e consequentemente, aos efeitos da sinalização via P2X7 pela ligação ao ATP.

Os mecanismos por trás da resposta deficiente dos animais $\mathrm{P} 2 \mathrm{X} 7^{-1-}$ são desconhecidos, e em busca de elucidá-los, passamos a estudar o baço destes animais ao longo da infecção pelo $P$. chabaudi. Sabendo-se da importância dos fagócitos do baço no controle da parasitemia e, consequentemente, na formação da resposta imunológica ao Plasmodium, buscou-se estudar as populações que expressam os marcadores CD11c, F4/80, CD11b, Ly6C e Ly6G presentes normalmente em células dendríticas, macrófagos, monócitos e neutrófilos [47, 53]. $O$ aumento no número total de células do baço dos camundongos C57BL/6 apresentado na Figura 5a está de acordo com o que já é descrito para a celularidade do baço no $7^{\circ}$ dia de infecção pelo $P$. chabaudi $[54,55]$. Da mesma forma, o aumento do número das células $\mathrm{CD} 11 \mathrm{c}^{+}$e $\mathrm{F} 4 / 80^{+}$no $7^{\circ}$ dia de infecção no baço dos camundongos C57BL/6 também já havia sido descrito por Leisewitz et al. [54]. Os camundongos $\mathrm{P} 2 \mathrm{X} 7^{-1-}$ também apresentaram um aumento no número de 
células totais do baço, porém de forma muito menos expressiva do que os animais C57BL/6, o que resultou em uma diferença significativa no número de células do baço entre as duas linhagens no dia 7 pós-infecção. Assim como para a celularidade total, o número de fagócitos $\mathrm{CD}_{11 \mathrm{C}^{+}}$e $\mathrm{F} 4 / 80^{+}$também foi menor no baço dos animais knockouts ao $7^{\circ}$ dia de infecção. Experimentos realizados a fim de avaliar o infiltrado inflamatório na obstrução renal constataram menor número de macrófagos $\mathrm{F} 4 / 80^{+}$infiltrados no rim dos animais $\mathrm{P} 2 \times 7^{-/-}$quando comparado aos animais C57BL/6 [56], o que consiste em mais um exemplo de contexto inflamatório onde os animais $\mathrm{P} 2 \times 7^{-/-}$apresentam menos células fagocíticas. A mesma diferença em número de células vista para as populações $\mathrm{CD}_{11} \mathrm{c}^{+}$e $\mathrm{F} 4 / 80^{+}$não foi observada no caso da população $\mathrm{CD} 11 \mathrm{~b}^{+}$total do baço dos animais. Analisando-se separadamente as subpopulações $C D 11 b^{+}$, vimos que a população CD11 ${ }^{+}$Ly6C $C^{\text {high }}$ não apresentou grandes diferenças em número de células entre os camundongos $\mathrm{C} 57 \mathrm{BL} / 6$ e $\mathrm{P} 2 \mathrm{X}^{-/-}$nos animais controle, e apresentou apenas uma leve tendência a um menor número de células no baço dos animais knockouts após 7 dias de infecção. Sponaas et al. mostraram que somente após 10 dias de infecção pelo $P$. chabaudi é visto um aumento significativo no número de monócitos [57]. Diante disto, podemos sugerir que a diferença encontrada no número de células das populações $C D 11 \mathrm{c}^{+}$e $\mathrm{F} 4 / 80^{+}$entre os animais C57BL/6 e P2X7/- apareça para esta população $C D 11 b^{+}$Ly6C $^{\text {high }}$ apenas após 10 dias de infecção, uma vez que é nesse período que esta população aumenta seu número de células de modo expressivo neste modelo de infecção no animal C57BL/6. Já para a população CD11 b Ly6G $^{+}$ observamos um comportamento contrário às demais populações celulares. Tanto nos animais não-infectados, como após 7 dias de infecção pelo $P$. chabaudi, foi observada uma tendência a um maior número de células desta população no baço dos animais $\mathrm{P} 2 \mathrm{X} 7^{-/-}$em relação aos animais C57BL/6. Talvez este seja o principal fator que levou a ausência de diferença no número de células entre as duas linhagens para a população $C D 11 b^{+}$total no baço após 7 dias de infecção. O efeito de aumento no número de neutrófilos em resposta à infecção nos camundongos $\mathrm{P} 2 \mathrm{X} 7^{-/-}$foi um achado inesperado, uma vez que dados da literatura costumam associar a ausência do receptor $\mathrm{P} 2 \mathrm{X} 7$ à redução do infiltrado inflamatório, incluindo os neutrófilos, como, por exemplo, descreveu Riteau et al. no caso da inflamação e fibrose pulmonar induzida [58]. Uma hipótese formulada para este resultado é a influência do receptor $\mathrm{P} 2 \mathrm{X} 7$ na morte celular dos neutrófilos. Como já foi citado 
anteriormente, o P2X7 é um receptor envolvido também na morte celular, e diante do fato de os neutrófilos serem células de meia-vida curta, talvez a morte celular envolvida na renovação neutrofílica esteja relacionada com a sinalização via receptor $\mathrm{P} 2 \mathrm{X} 7$, de forma que esta renovação seja prejudicada e um maior número de neutrófilos se acumule no organismo. Diversos estudos adicionais são necessários para avaliar esta hipótese, e estes estão inclusos nos planos do grupo de pesquisa para elucidar o fenômeno encontrado. Em relação ao número de células, avaliamos também as populações leucocitárias presentes no fígado em resposta à infecção pelo $P$. chabaudi, encontrando um padrão fenotípico muito semelhante ao encontrado no baço dos animais $\mathrm{C} 57 \mathrm{BL} / 6$ e $\mathrm{P} 2 \times 7^{-/}$. Além dos fagócitos, foi analisado também o número de células pertencentes à linhagem linfoide, os linfócitos $\mathrm{T} \mathrm{CD4}^{+}$e os linfócitos $\mathrm{T} \mathrm{CD} 8^{+}$, os quais apresentaram o mesmo padrão de número inferior de células presente no fígado dos animais $\mathrm{P} 2 \mathrm{X} 7^{-1-}$. O aumento do número de células $\mathrm{T} C D 4^{+}$e $\mathrm{T} C D 8^{+}$no fígado no $7^{\circ}$ dia de infecção pelo $P$. chabaudi já foi descrito por Mastelic et al., corroborando com os dados aqui apresentados para os animais C57BL/6 [59]. Assim como foi apresentado para o baço, as populações fagocíticas $\mathrm{F} 4 / 80^{+}$e $\mathrm{CD} 11 \mathrm{~b}^{+}$Ly6 $\mathrm{C}^{\text {high }}$ possuíam menor número de células nos animais knockouts em comparação aos C57BL/6 no fígado $7^{\circ}$ dia pós-infecção. Além disso, dados do nosso grupo de pesquisa que não foram aqui apresentados também indicam menor número de células $\mathrm{T} \mathrm{CD}^{+} \mathrm{e} \mathrm{T} \mathrm{CD} 8^{+}$no baço dos animais $\mathrm{P} 2 \mathrm{X} 7^{-1}$, de forma a corroborar com a correlação encontrada entre o baço e o fígado para os fagócitos. Por fim, o fenômeno encontrado para a população $\mathrm{CD} 11 \mathrm{~b}^{+} \mathrm{Ly}_{6 \mathrm{G}}{ }^{+}$no baço, também se repetiu no fígado, porém de maneira menos proeminente no $7^{\circ}$ dia de infecção, de forma que a hipótese pode se estender para todo o sistema do camundongo $\mathrm{P} 2 \times 7^{--}$, uma vez que o neutrófilo é uma célula circulante. Foi observado, portanto, no fígado e no baço, com exceção da população $\mathrm{CD} 11 \mathrm{~b}^{+} \mathrm{Ly}_{6 \mathrm{G}}{ }^{+}$, uma deficiência em número das células do sistema imunológico no camundongo $\mathrm{P} 2 \mathrm{X} 7^{-1}$. Toda essa resposta celular deficiente, com menor número de fagócitos presentes no baço e fígado, pode ser uma das causas da parasitemia persistente e até com maiores níveis nos animais $\mathrm{P} 2 \times 7^{-1-}$ quando comparados aos animais C57BL/6 na infecção pelo $P$. chabaudi, embora seja necessário avaliar outros aspectos da resposta destes animais para confirmar esta hipótese. 
A ativação celular dos fagócitos é essencial para que estes executem suas funções efetoras de eliminação do patógeno e apresentação antigênica de forma funcional. Desta forma, avaliamos a expressão das moléculas CD80 e MHC II nas populações fagocíticas $\mathrm{CD} 11 \mathrm{c}^{+}, \mathrm{CD} 11 \mathrm{~b}^{+}$e $\mathrm{F} 4 / 80^{+}$do baço. Conforme apresentado, a população $\mathrm{CD} 11 \mathrm{c}^{+}$apresentou aumento nos níveis de CD80 em resposta à infecção, porém este aumento se deu de forma equivalente para ambas as linhagens C57BL/6 e $\mathrm{P} 2 \mathrm{X}^{-/}$. A expressão de $\mathrm{MHC}$ II nesta população $\mathrm{CD} 11 \mathrm{c}^{+}$se manteve constante na ausência e na presença da infecção e sem diferença entre os animais C57BL/6 e $\mathrm{P} 2 \times 7^{-1-}$. Já a população $\mathrm{CD} 11 \mathrm{~b}^{+}$do baço dos animais C57BL/6 apresenta um aumento na expressão de CD80 no $7^{\circ}$ dia de infecção em relação aos animais não infectados e uma manutenção dos níveis de expressão de MHC II já apresentados nos animais não infectados. No modelo murino de infecção pelo $P$. yoelli, foi observado o aumento da expressão de CD80 e MHC II pela população CD11 ${ }^{+}$ao longo da infecção [60]. No entanto, a população $\mathrm{CD} 11 \mathrm{~b}^{+}$do baço dos camundongos $\mathrm{P} 2 \times 7^{-1-}$ mostrou-se menos ativa quando comparada à mesma população dos animais C57BL/6, expressando menores níveis de CD80 no $7^{\circ}$ dia de infecção. O fenômeno encontrado no caso da população $F 4 / 80$ foi o de redução da expressão de $\mathrm{CD} 80$ em resposta à infecção, com as células $\mathrm{F} 4 / 80^{+}$do baço dos animais $\mathrm{C} 57 \mathrm{BL} / 6$ e P2X7/- expressando níveis significativamente menores no $7^{\circ}$ dia de infecção em comparação aos animais não-infectados. Entretanto, os níveis de CD80 expressos no $7^{\circ}$ dia de infecção pelas células $\mathrm{F} 4 / 80^{+}$dos animais C57BL/6 apresentaram-se ainda significativamente menores do que aqueles expressos pelas células dos animais $\mathrm{P} 2 \mathrm{X} 7^{-1}$, indicando que, se a resposta à infecção implica em redução da expressão de CD80 por esta população celular, as células dos animais C57BL/6 estão respondendo de maneira mais adequada. Em relação à expressão de MHC II, foi observado o mesmo fenômeno de redução da expressão em resposta à infecção, no entanto, não foram observadas diferenças na expressão de MHC II entre as células dos animais C57BL/6 e P2X7 $7^{-1}$. Não foi possível observar influência do receptor P2X7 na expressão de $M H C$ II nas populações $C D 11 C^{+}, C D 11 b^{+}$e F4/80 ${ }^{+}$ seja na expressão basal desta molécula nestas células ou em resposta à infecção pelo $P$. chabaudi. Entretanto, a expressão de CD80 pareceu sofrer influência da sinalização via receptor $P 2 X 7$ nas populações $C D 11 b^{+}$e $F 4 / 80^{+}$. Wilhelm et al. observaram que a estimulação pelo ATP leva ao aumento da expressão de CD80 e CD86 nas células apresentadoras de antígeno tanto in vitro, como in vivo [61] e 
diversos estudos associam a sinalização via P2X7 com a ativação de linfócitos T [41, 62], indicando que este receptor possui um papel na ativação celular e que, no nosso modelo experimental de malária, pode estar influenciando na ativação e consequente aumento da expressão de $\mathrm{CD} 80$ na população $\mathrm{CD} 11 \mathrm{~b}^{+}$ou redução da expressão desta mesma molécula na população $\mathrm{F} 4 / 80^{+}$do baço.

Sabendo-se que as células fagocíticas podem atuar como apresentadoras de antígeno e induzir a produção de IFN- $\gamma$ pelas células $T$ [60], consideramos importante avaliar o estado de produção desta citocina nos camundongos deficientes para o receptor P2X7. Nossos resultados sugerem que a produção de IFN-y é prejudicada na ausência do $\mathrm{P} 2 \mathrm{X} 7$, uma vez que a concentração desta citocina na cultura de fagócitos do baço com células $\mathrm{T} \mathrm{CD4^{+ }}$ de animais infectados é significativamente menor quando as células foram extraídas de animais $\mathrm{P} 2 \mathrm{X} 7^{-/-} \mathrm{em}$ comparação às células dos camundongos C57BL/6. Além disso, no baço de animais com 7 dias de infecção também observamos um número inferior de células T CD4 ${ }^{+}$ produtoras de IFN-y nos camundongos $\mathrm{P} 2 \mathrm{X} 7^{-/}$em relação aos $\mathrm{C} 57 \mathrm{BL} / 6$, o que pode ser reflexo do número total de células que já é inferior nestes animais, assim como de uma ativação defeituosa destas células para a produção de IFN-y pelos fagócitos. Muitos estudos já mostraram que o IFN-y é produzido em altos níveis na fase aguda dos modelos murinos de malária, sendo uma citocina essencial no controle do pico de parasitemia [18, 60, 63, 64]. Embora Miller et al. não observaram mudanças na produção de IFN-y em camundongos $\mathrm{P} 2 X 7^{-/}$infectados com Toxoplasma gondii [49], estudos com inibidores do receptor P2X7 indicam que este receptor é capaz de influenciar a produção e função desta citocina [61, 65], assim como o apresentado nos resultados. A redução do número de células produtoras, assim como da produção total, de IFN-y seria, portanto, um fator que favorece a piora no quadro da malária desenvolvida pelos animais $\mathrm{P} 2 \times 7^{-1 /}$.

A resposta à malária envolve a produção de citocinas pró-inflamatórias, como o TNF- $\alpha$, para proteção, porém também leva à produção de IL-10, com o intuito de manter o balanço entre a proteção ao parasito e a imunopatologia resultante de uma resposta exacerbada [66]. A produção de TNF- $\alpha$ e IL-10 por monócitos, macrófagos e células dendríticas já é conhecida [67-69], de forma que decidimos avaliar a produção destas citocinas por estas populações fagocíticas no baço dos animais C57BL/6 e P2X7 $7^{-1}$ infectados pelo $P$. chabaudi. Assim como encontrado para o IFN$\mathrm{Y}$, o número de células $\mathrm{CD} 11 \mathrm{c}^{+}$e células $\mathrm{F} 4 / 80^{+}$produtoras de $\mathrm{IL}-10$ foi menor nos 
animais knockouts quando comparados aos C57BL/6, o que, mais uma vez, pode ser reflexo da redução do número total de células neste animais. Embora um aumento na produção de IL-10 pudesse justificar a redução na produção de IFN- $\gamma$ e, possivelmente, o aumento da suscetibilidade dos animais $\mathrm{P} 2 \mathrm{X}^{-/-}$à infecção, este resultado não foi o encontrado e pode ser justificado pelo fato de a produção de IL10 poder ser regulada pelo IFN- $\gamma$, assim como foi visto para macrófagos em resposta ao LPS [70]. Apesar da baixa deteç̧ão intracelular, o número de células CD11c ${ }^{+}$ produtoras de TNF- $\alpha$ acompanhou o mesmo comportamento no estudos das demais citocinas, no entanto, estas células apresentaram-se também em menor frequência, além de número absoluto, no baço dos animais $\mathrm{P} 2 \mathrm{X}^{-/-}$em relação aos $\mathrm{C} 57 \mathrm{BL} / 6$, o que indica que este resultado não seja apenas uma consequência do número total de células menor nos animais knockouts. Já a população $\mathrm{F} 4 / 80^{+}$produtora de TNF- $\alpha$ não apresentou diferenças entre os animais $\mathrm{C} 57 \mathrm{BL} / 6$ e $\mathrm{P} 2 \mathrm{X} 7^{-1}$, o que pode ser resultado de uma falha na deteç̧ão intracelular desta citocina nesta população, já que os valores obtidos foram baixos. A produção de TNF- $\alpha$ em altos níveis em resposta à malária é um evento bem descrito na literatura tanto nos modelos murinos, como em humanos [71-73]. A influência do P2X7 na produção de TNF- $\alpha$ também já foi descrita por diversos autores, sendo que a ativação deste receptor via ATP parece ser capaz de induzir a produção de TNF- $\alpha$, o uso de inibidores do receptor $\mathrm{P} 2 \mathrm{X} 7$ leva à menor produção desta citocina e indivíduos que apresentam polimorfismos de perda de função deste receptor apresentam menores níveis de TNF- $\alpha$ no soro [74-76]. Tais estudos corroboram, portanto, com o resultado aqui apresentado que sugere uma deficiência nas células $\mathrm{CD} 11 \mathrm{c}^{+}$produtoras de TNF- $\alpha$ em camundongos $\mathrm{P} 2 \mathrm{X} 7^{-1-}$. 


\section{CONCLUSÃO}

Em resumo, os resultados aqui apresentados sugerem que o ATP e, consequentemente, o receptor $\mathrm{P} 2 \mathrm{X} 7$ que o reconhece possuem papel importante na malária, o que pôde ser observado na exacerbação da doença nos camundongos $\mathrm{P} 2 \mathrm{X7}^{-/}$. Além disso, foi visto que os fagócitos são células que sofrem efeito do ATP, tornando-se ainda mais sensíveis a esses efeitos em resposta à infecção pelo $P$. chabaudi. Dentre estes efeitos, apresentamos uma deficiência no número total de células esplênicas e das populações fagocíticas do baço em resposta à infecção nos animais $\mathrm{P} 2 \mathrm{X}^{-1-}$, assim como no número de células produtoras de citocinas importantes para a resposta à malária, como IL-10, TNF- $\alpha$ e IFN- $y$, com este último sendo produzido em menor quantidade pelas células deficientes para o receptor P2X7. Estudos fenotípicos de expressão de moléculas relacionadas à ativação de fagócitos indicaram que o receptor $\mathrm{P} 2 \mathrm{X} 7$ parece ter um papel na expressão de CD80 pelas células fagocíticas do baço na resposta à infecção, o que pode implicar em defeitos na ativação da resposta, já deficiente em número de células. Por fim, também foi verificado que, não apenas no baço, mas também no fígado, a deficiência no número de células nos animais $\mathrm{P} 2 \mathrm{X} 7^{-1-}$ acomete as populações de fagócitos e de linfócitos.

Tais observações permitem inferir que os animais $\mathrm{P} 2 \mathrm{X} 7^{-1-}$ apresentam uma resposta imunológica deficiente ao $P$. chabaudi de forma geral, representada principalmente pelo menor número de células esplênicas e no fígado, o que leva à menor produção de citocinas e outras moléculas efetoras nestes animais, de modo que não conseguem combater a infecção de maneira eficiente, apresentando um quadro mais severo da doença, incluindo letalidade, em relação aos animais C57BL/6. 


\section{REFERÊNCIAS*}

1. Tuteja R, Malaria - an overview. FEBS J. 2007;274(18):4670-9.

2. World Health Organization. Malaria World Report 2011. Geneva; 2011.

3. Jongwutiwes S, Putaporntip C, Iwasaki T, Sata T, Kanbara H. Naturally acquired Plasmodium knowlesi malaria in human, Thailand. Emerg Infect Dis. 2004;10(12):2211-3.

4. White NJ. Plasmodium knowlesi: the fifth human malaria parasite. Clin Infect Dis. 2008;46(2):172-3.

5. Plowe CV, Alonso P, Hoffman SL. The potential role of vaccines in the elimination of falciparum malaria and the eventual eradication of malaria. $\mathrm{J}$ Infect Dis. 2009;200(11):1646-9.

6. Thera MA, Plowe CV. Vaccines for malaria: how close are we? Annu Rev Med. 2012;63:345-57.

7. Protzer U, Maini MK, Knolle PA. Living in the liver: hepatic infections. Nat Rev Immunol. 2012;12(3):201-13.

8. Krishnegowda G, Hajjar AM, Zhu J, Douglass EJ, Uematsu S, Akira S, Woods AS, Gowda DC. Induction of proinflammatory responses in macrophages by the glycosylphosphatidylinositols of Plasmodium falciparum: cell signaling receptors, glycosylphosphatidylinositol (GPI) structural requirement, and regulation of GPI activity. J Biol Chem. 2005;280(9):8606-16.

9. Nebl T, De Veer MJ, Schofield L. Stimulation of innate immune responses by malarial glycosylphosphatidylinositol via pattern recognition receptors. Parasitology. 2005;130 Suppl:S45-62.

10. Coban C, Ishii KJ, Kawai T, Hemmi H, Sato S, Uematsu S, Yamamoto M, Takeuchi O, Itagaki S, Kumar N, Horii T, Akira S. Toll-like receptor 9 mediates innate immune activation by the malaria pigment hemozoin. J Exp Med. 2005;201(1):19-25.

11. Erdman LK, Cosio G, Helmers AJ, Gowda DC, Grinstein S, Kain KC. CD36 and TLR interactions in inflammation and phagocytosis: implications for malaria. J Immunol. 2009;183(10):6452-9.

12. Serghides L, Smith TG, Patel SN, Kain KC. CD36 and malaria: friends or foes? Trends Parasitol. 2003;19(10):461-9.

*De acordo com:

International Committee of Medical Journal Editors. [Internet]. Uniform requirements for manuscripts submitted to Biomedical Journal: sample references. [updated $2011 \mathrm{Jul} 15$ ].

Available from: http://www.icmje.org 
13. McGilvray ID, Serghides L, Kapus A, Rotstein OD, Kain KC. Nonopsonic monocyte/macrophage phagocytosis of Plasmodium falciparum-parasitized erythrocytes: a role for CD36 in malarial clearance. Blood. 2000;96(9):323140.

14. Miller JM, Boyd HA, Ostrowski SR, Cookson ST, Parise ME, Gonzaga PS, Addiss DG, Wilson M, Nguyen-Dinh P, Wahlquist SP, Weld LH, Wainwright RB, Gushulak BD, Cetron MS. Malaria, intestinal parasites, and schistosomiasis among Barawan Somali refugees resettling to the United States: a strategy to reduce morbidity and decrease the risk of imported infections. Am J Trop Med Hyg. 2000;62(1):115-21.

15. Daniel-Ribeiro C, de Oliveira-Ferreira J, Banic DM, Galvao-Castro B. Can malaria-associated polyclonal B-lymphocyte activation interfere with the development of anti-sporozoite specific immunity? Trans R Soc Trop Med Hyg. 1989;83(3):289-92.

16. Gupta S, Snow RW, Donnelly CA, Marsh K, Newbold C. Immunity to noncerebral severe malaria is acquired after one or two infections. Nat Med. 1999;5(3):340-3.

17. Langhorne J, Ndungu FM, Sponaas AM, Marsh K. Immunity to malaria: more questions than answers. Nat Immunol. 2008;9(7):725-32.

18. Stevenson MM Riley EM. Innate immunity to malaria. Nat Rev Immunol. 2004;4(3):169-80.

19. Lyke KE, Burges R, Cissoko Y, Sangare L, Dao M, Diarra I, Kone A, Harley R, Plowe CV, Doumbo OK, Sztein MB. Serum levels of the proinflammatory cytokines interleukin-1 beta (IL-1beta), IL-6, IL-8, IL-10, tumor necrosis factor alpha, and IL-12(p70) in Malian children with severe Plasmodium falciparum malaria and matched uncomplicated malaria or healthy controls. Infect Immun, 2004;72(10):5630-7.

20. Ochiel DO, Awandare GA, Keller CC, Hittner JB, Kremsner PG, Weinberg JB, Perkins DJ. Differential regulation of beta-chemokines in children with Plasmodium falciparum malaria. Infect Immun. 2005;73(7):4190-7.

21. Anstey NM, Weinberg JB, Hassanali MY, Mwaikambo ED, Manyenga D, Misukonis MA, Arnelle DR, Hollis D, McDonald MI, Granger DL. Nitric oxide in Tanzanian children with malaria: inverse relationship between malaria severity and nitric oxide production/nitric oxide synthase type 2 expression. J Exp Med. 1996;184(2):557-67.

22. Artavanis-Tsakonas K, Tongren JE, Riley EM. The war between the malaria parasite and the immune system: immunity, immunoregulation and immunopathology. Clin Exp Immunol. 2003;133(2):145-52.

23. Tang D, Kang R, Coyne CB, Zeh HJ, Lotze MT. PAMPs and DAMPs: signal Os that spur autophagy and immunity. Immunol Rev. 2012;249(1):158-75. 
24. Bours MJ, Swennen EL, Di Virgilio F, Cronstein BN, Dagnelie PC. Adenosine 5 '-triphosphate and adenosine as endogenous signaling molecules in immunity and inflammation. Pharmacol Ther. 2006;112(2):358-404.

25. Ayi K, Liles WC, Gros P, Kain KC. Adenosine triphosphate depletion of erythrocytes simulates the phenotype associated with pyruvate kinase deficiency and confers protection against Plasmodium falciparum in vitro. J Infect Dis. 2009;200(8):1289-99.

26. Cox J, Semoff S, Hommel M. Plasmodium chabaudi: a rodent malaria model for in-vivo and in-vitro cytoadherence of malaria parasites in the absence of knobs. Parasite Immunol. 1987;9(5):543-61.

27. Falanga PB, D'Imperio Lima MR, Coutinho A, Pereira da Silva L. Isotypic pattern of the polyclonal $B$ cell response during primary infection by Plasmodium chabaudi and in immune-protected mice. Eur $\mathrm{J}$ Immunol. 1987;17(5):599-603.

28. Sardinha LR, D'Imperio Lima MR, Alvarez JM. Influence of the polyclonal activation induced by Plasmodium chabaudi on ongoing OVA-specific B- and T-cell responses. Scand J Immunol. 2002;56(4):408-16.

29. Langhorne J, Quin SJ, Sanni LA. Mouse models of blood-stage malaria infections: immune responses and cytokines involved in protection and pathology. Chem Immunol. 2002;80:204-28.

30. Su Z, Stevenson MM. Central role of endogenous gamma interferon in protective immunity against blood-stage Plasmodium chabaudi AS infection. Infect Immun. 2000;68(8):4399-406.

31. Bastos KR, Barboza R, Elias RM, Sardinha LR, Grisotto MG, Marinho CR, Amarante-Mendes GP, Alvarez JM, Lima MR. Impaired macrophage responses may contribute to exacerbation of blood-stage Plasmodium chabaudi chabaudi malaria in interleukin-12-deficient mice. J Interferon Cytokine Res. 2002;22(12):1191-9.

32. Langhorne J, Albano FR, Hensmann M, Sanni L, Cadman E, Voisine C, Sponaas AM. Dendritic cells, pro-inflammatory responses, and antigen presentation in a rodent malaria infection. Immunol Rev. 2004;201:35-47.

33. Helmby $\mathrm{H}$, Jonsson $\mathrm{G}$, Troye-Blomberg $\mathrm{M}$. Cellular changes and apoptosis in the spleens and peripheral blood of mice infected with blood-stage Plasmodium chabaudi chabaudi AS. Infect Immun. 2000;68(3):1485-90.

34. Freitas do Rosario AP, Muxel SM, Rodriguez-Malaga SM, Sardinha LR, Zago CA, Castillo-Mendez SI, Alvarez JM, D'Imperio Lima MR. Gradual decline in malaria-specific memory $T$ cell responses leads to failure to maintain longterm protective immunity to Plasmodium chabaudi AS despite persistence of $B$ cell memory and circulating antibody. J Immunol. 2008;181(12):8344-55. 
35. Junger WG. Immune cell regulation by autocrine purinergic signalling. Nat Rev Immunol. 2011;11(3):201-12.

36. Jarvis MF, Khakh BS. ATP-gated P2X cation-channels. Neuropharmacology. 2009;56(1):208-15.

37. Aga M, Watters JJ, Pfeiffer ZA, Wiepz GJ, Sommer JA, Bertics PJ. Evidence for nucleotide receptor modulation of cross talk between MAP kinase and NFkappa B signaling pathways in murine RAW 264.7 macrophages. Am J Physiol Cell Physiol. 2004;286(4):C923-30.

38. Jin C, Flavell RA. Molecular mechanism of NLRP3 inflammasome activation. J Clin Immunol. 2010;30(5):628-31.

39. Sperlagh B, Hasko G, Nemeth Z, Vizi ES. ATP released by LPS increases nitric oxide production in raw 264.7 macrophage cell line via P2Z/P2X7 receptors. Neurochem Int. 1998;33(3):209-15.

40. Monif M, Burnstock G, Williams DA. Microglia: proliferation and activation driven by the P2X7 receptor. Int J Biochem Cell Biol. 2010;42(11):1753-6.

41. Yip L, Woehrle $T$, Corriden $R$, Hirsh $M$, Chen $Y$, Inoue $Y$, Ferrari V, Insel PA, Junger WG. Autocrine regulation of T-cell activation by ATP release and P2X7 receptors. FASEB J. 2009;23(6):1685-93.

42. Moon $\mathrm{H}, \mathrm{Na} \mathrm{HY}$, Chong KH, Kim TJ. P2X7 receptor-dependent ATP-induced shedding of CD27 in mouse lymphocytes. Immunol Lett. 2006;102(1):98-105.

43. Labasi JM, Petrushova N, Donovan C, McCurdy S, Lira P, Payette MM, Brissette W, Wicks JR, Audoly L, Gabel CA. Absence of the P2X7 receptor alters leukocyte function and attenuates an inflammatory response. J Immunol. 2002;168(12):6436-45.

44. Adinolfi E, Pizzirani C, Idzko M, Panther E, Norgauer J, Di Virgilio F, Ferrari D. P2X(7) receptor: Death or life? Purinergic Signal. 2005;1(3):219-27.

45. Tsukimoto $M$, Maehata $M$, Harada $H$, Ikari A, Takagi K, Degawa M. P2X7 receptor-dependent cell death is modulated during murine $\mathrm{T}$ cell maturation and mediated by dual signaling pathways. J Immunol. 2006;177(5):2842-50.

46. Weischenfeldt J, Porse B. Bone Marrow-Derived Macrophages (BMM): Isolation and Applications. CSH Protoc. 2008;2008:prot5080.

47. Rose S, Misharin A, Perlman H. A novel Ly6C/Ly6G-based strategy to analyze the mouse splenic myeloid compartment. Cytometry A. 2012;81(4):343-50.

48. Segura M, Matte C, Thawani N, Su Z, Stevenson MM. Modulation of malariainduced immunopathology by concurrent gastrointestinal nematode infection in mice. Int J Parasitol. 2009;39(14):1525-32. 
49. Miller CM, Zakrzewski AM, Ikin RJ, Boulter NR, Katrib M, Lees MP, Fuller SJ, Wiley JS, Smith NC. Dysregulation of the inflammatory response to the parasite, Toxoplasma gondii, in P2X7 receptor-deficient mice. Int J Parasitol. 2011;41(3-4):301-8.

50. Wiley JS, Sluyter R, Gu BJ, Stokes L, Fuller SJ. The human P2X7 receptor and its role in innate immunity. Tissue Antigens. 2011;78(5):321-32.

51. Le Feuvre RA, Brough D, Iwakura Y, Takeda K, Rothwell NJ. Priming of macrophages with lipopolysaccharide potentiates P2X7-mediated cell death via a caspase-1-dependent mechanism, independently of cytokine production. J Biol Chem. 2002;277(5):3210-8.

52. Humphreys BD, Dubyak GR. Modulation of $P 2 X 7$ nucleotide receptor expression by pro- and anti-inflammatory stimuli in THP-1 monocytes. J Leukoc Biol. 1998;64(2):265-73.

53. Nagaoka K, Takahara K, Minamino K, Takeda T, Yoshida Y, Inaba K. Expression of C-type lectin, SIGNR3, on subsets of dendritic cells, macrophages, and monocytes. J Leukoc Biol. 2010;88(5):913-24.

54. Leisewitz AL, Rockett KA, Gumede B, Jones M, Urban B, Kwiatkowski DP. Response of the splenic dendritic cell population to malaria infection. Infect Immun. 2004;72(7):4233-9.

55. Elias RM, Sardinha LR, Bastos KR, Zago CA, da Silva AP, Alvarez JM, Lima MR. Role of CD28 in polyclonal and specific $T$ and $B$ cell responses required for protection against blood stage malaria. J Immunol. 2005;174(2):790-9.

56. Goncalves RG, Gabrich L, Rosario A, Jr., Takiya CM, Ferreira ML, Chiarini LB, Persechini PM, Coutinho-Silva R, Leite M, Jr.. The role of purinergic P2X7 receptors in the inflammation and fibrosis of unilateral ureteral obstruction in mice. Kidney Int. 2006;70(9):1599-606.

57. Sponaas AM, Freitas do Rosario AP, Voisine C, Mastelic B, Thompson J, Koernig S, Jarra W, Renia L, Mauduit M, Potocnik AJ, Langhorne J. Migrating monocytes recruited to the spleen play an important role in control of blood stage malaria. Blood. 2009;114(27):5522-31.

58. Riteau N, Gasse P, Fauconnier L, Gombault A, Couegnat M, Fick L, Kanellopoulos J, Quesniaux VF, Marchand-Adam S, Crestani B, Ryffel B, Couillin I. Extracellular ATP is a danger signal activating P2X7 receptor in lung inflammation and fibrosis. Am J Respir Crit Care Med. 2010;182(6):774-83.

59. Mastelic B, do Rosario AP, Veldhoen M, Renauld JC, Jarra W, Sponaas AM, Roetynck S, Stockinger B, Langhorne J. IL-22 Protects Against Liver Pathology and Lethality of an Experimental Blood-Stage Malaria Infection. Front Immunol. 2012;3:85. 
60. Luyendyk J, Olivas OR, Ginger LA, Avery AC. Antigen-presenting cell function during Plasmodium yoelii infection. Infect Immun. 2002;70(6):2941-9.

61. Wilhelm K, Ganesan J, Muller T, Durr C, Grimm M, Beilhack A, Krempl CD, Sorichter S, Gerlach UV, Juttner E, Zerweck A, Gartner F, Pellegatti P, Di Virgilio F, Ferrari D, Kambham N, Fisch P, Finke J, Idzko M, Zeiser R. Graftversus-host disease is enhanced by extracellular ATP activating P2X7R. Nat Med. 2010;16(12):1434-8.

62. Tsukimoto M, Tokunaga A, Harada H, Kojima S. Blockade of murine $\mathrm{T}$ cell activation by antagonists of P2Y6 and P2X7 receptors. Biochem Biophys Res Commun. 2009;384(4):512-8.

63. Langhorne J, Gillard S, Simon B, Slade S, Eichmann K. Frequencies of CD4+ $T$ cells reactive with Plasmodium chabaudi chabaudi: distinct response kinetics for cells with Th1 and Th2 characteristics during infection. Int Immunol. 1989;1(4):416-24.

64. van der Heyde HC, Pepper B, Batchelder J, Cigel F, Weidanz WP. The time course of selected malarial infections in cytokine-deficient mice. Exp Parasitol. 1997;85(2):206-13.

65. Gendron FP, Chalimoniuk M, Strosznajder J, Shen S, Gonzalez FA, Weisman GA, Sun GY. P2X7 nucleotide receptor activation enhances IFN gammainduced type II nitric oxide synthase activity in BV-2 microglial cells. J Neurochem. 2003;87(2):344-52.

66. Freitas do Rosario AP, Lamb T, Spence P, Stephens R, Lang A, Roers A, Muller W, O'Garra A, Langhorne J. IL-27 promotes IL-10 production by effector Th1 CD4+ T cells: a critical mechanism for protection from severe immunopathology during malaria infection. J Immunol. 2012;188(3):1178-90.

67. Moore KW, de Waal Malefyt R, Coffman RL, O'Garra A. Interleukin-10 and the interleukin-10 receptor. Annu Rev Immunol. 2001;19:683-765.

68. Bamboat ZM, Ocuin LM, Balachandran VP, Obaid H, Plitas G, DeMatteo RP. Conventional DCs reduce liver ischemia/reperfusion injury in mice via IL-10 secretion. J Clin Invest. 2010;120(2):559-69.

69. Gasparini C, Foxwell BM, Feldmann M. RelB/p50 regulates TNF production in LPS-stimulated dendritic cells and macrophages. Cytokine. 2013;61(3):73640.

70. Chang EY, Guo B, Doyle SE, Cheng G. Cutting edge: involvement of the type I IFN production and signaling pathway in lipopolysaccharide-induced IL-10 production. J Immunol. 2007;178(11):6705-9.

71. Boeuf PS, Loizon S, Awandare GA, Tetteh JK, Addae MM, Adjei GO, Goka B, Kurtzhals JA, Puijalon O, Hviid L, Akanmori BD, Behr C. Insights into 
deregulated TNF and IL-10 production in malaria: implications for understanding severe malarial anaemia. Malar J. 2012;11:253.

72. Scragg IG, Hensmann M, Bate CA, Kwiatkowski D. Early cytokine induction by Plasmodium falciparum is not a classical endotoxin-like process. Eur $\mathrm{J}$ Immunol. 1999;29(8):2636-44.

73. Li C, Sanni LA, Omer F, Riley E, Langhorne J. Pathology of Plasmodium chabaudi chabaudi infection and mortality in interleukin-10-deficient mice are ameliorated by anti-tumor necrosis factor alpha and exacerbated by antitransforming growth factor beta antibodies. Infect Immun. 2003;71(9):4850-6.

74. Lister MF, Sharkey J, Sawatzky DA, Hodgkiss JP, Davidson DJ, Rossi AG, Finlayson $\mathrm{K}$. The role of the purinergic P2X7 receptor in inflammation. $J$ Inflamm (Lond). 2007;4:5.

75. Suzuki T, Hide I, Ido K, Kohsaka S, Inoue K, Nakata Y. Production and release of neuroprotective tumor necrosis factor by $\mathrm{P} 2 \mathrm{X} 7$ receptor-activated microglia. J Neurosci. 2004;24(1):1-7.

76. Guerra AN, Fisette PL, Pfeiffer ZA, Quinchia-Rios BH, Prabhu U, Aga M, Denlinger LC, Guadarrama AG, Abozeid S, Sommer JA, Proctor RA, Bertics PJ. Purinergic receptor regulation of LPS-induced signaling and pathophysiology. J Endotoxin Res. 2003;9(4):256-63. 